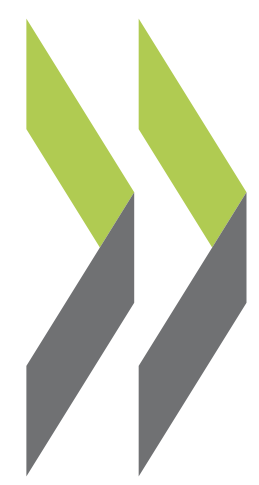

OECD Economics Department Working Papers No. 572

Austria's Deepening Economic Integration with Rina Bhattacharya Central and Eastern Europe 
ECONOMICS DEPARTMENT

by

\section{Rina Bhattacharya}

All OECD Economics Department Working Papers are available on the OECD Internet website at www.oecd.org/eco/working_papers 


\section{ABSTRACT/RÉSUMÉ}

\section{Austria's deepening economic integration with Central and Eastern Europe}

The Austrian economy has benefited substantially from the expansion of economic ties with Central and Eastern Europe, which has provided a significant boost to growth, productivity, competitiveness, profits and (more controversially) aggregate employment. Indeed, among the older EU member states, Austria has benefited the most from the transition of the Central and Eastern European countries from planned economies to market economies, and the subsequent entry into the EU of the ten new member states, mostly from Central and Eastern Europe, in 2004. However, important segments of the population in Austria, and in particular low-skilled and semi-skilled workers in the manufacturing sector, appear to have been adversely affected by these developments. There is thus a need for policy measures to help those segments of the workforce that have had difficulty coping with growing competition from Central and Eastern Europe. Furthermore, more can be done to make Austria a more attractive location for highly skilled and well qualified expatriate workers and to maintain Vienna's position as a central hub for multinationals operating in the region. These include, in particular, the need to strengthen eastern transportation links and to reduce to a minimum bureaucratic hurdles and red tape for foreign enterprises seeking to operate out of Vienna.

This Working Paper relates to the 2007 Economic Survey of Austria (www.oecd.org/eco/surveys/austria).

$$
\text { JEL classification : F15, F23 }
$$

Keywords: Regional integration; globalisation; competitiveness; productivity; growth; employment; profitability

$$
* * * * * * *
$$

\section{L'intégration économique croissante de l'Autriche avec l'Europe centrale et orientale}

L'économie autrichienne a fortement bénéficié du développement de ses relations économiques avec l'Europe centrale et orientale, qui a sensiblement renforcé la croissance, la productivité, la compétitivité et les bénéfices des entreprises, ainsi que l'emploi total - encore que le bilan soit plus mitigé à cet égard. En fait, parmi les anciens États membres de l'Union européenne (UE), c'est l'Autriche qui a tiré le plus grand profit de la transition des pays d'Europe centrale et orientale (PECO) de l'économie planifiée vers l'économie de marché, puis de l'adhésion des dix nouveaux États membres, situés pour la plupart en Europe centrale et orientale, qui ont rejoint l'UE en 2004. Néanmoins, il semble que ces évolutions aient eu des conséquences préjudiciables sur des segments importants de la population autrichienne, en particulier sur les travailleurs peu qualifiés et semi-qualifiés du secteur manufacturier. Les pouvoirs publics doivent donc prendre des mesures pour aider les catégories de main-d'œuvre ayant des difficultés à faire face à la concurrence croissante des PECO. En outre, les autorités peuvent déployer davantage d'efforts pour rendre le territoire autrichien plus attractif pour les travailleurs expatriés hautement qualifiés et très compétents, ainsi que pour préserver la position de Vienne en tant que plaque tournante pour les multinationales présentes dans la région. À cet égard, il serait notamment nécessaire de renforcer les voies de communication orientales, ainsi que de réduire au minimum les obstacles bureaucratiques et les formalités administratives pour les entreprises étrangères qui souhaitent faire de Vienne leur base d'opérations.

Ce document de travail se rapporte à l'Étude économique de l'Autriche 2007 (www.oecd.org/eco/etudes/autriche).

Classifications JEL : F15, F23

Mots clés : intégration régionale ; mondialisation ; compétitivité ; productivité ; croissance ; emploi ; rentabilité

Copyright OECD, 2007

Application for permission to reproduce or translate all, or part of, this material should be made to: Head of Publications Service, OECD, 2 rue André Pascal, 75775 Paris Cedex 16, France. 


\section{TABLE OF CONTENTS}

Growing economic integration with Central and Eastern Europe ........................................................ 6

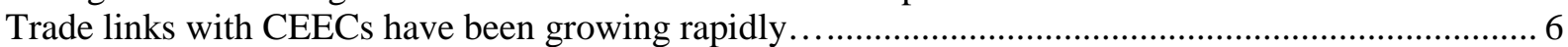

but more striking has been the expansion of Austria's foreign direct investment in CEECs.............. 11

... while immigration flows from CEECs have fluctuated considerably from year to year.................. 14

Positive overall impact on aggregate output and employment.............................................................. 16

Growing regional integration has affected Austria's economy through a multiple of channels............ 16

Most empirical studies show a positive overall impact on output and employment. ............................ 17

Some segments of the population and workforce have been adversely affected .................................... 18

The effects of foreign direct investment have varied across sectors and skill levels............................ 18

Regional integration has given a boost to productivity, competitiveness and profitability..................... 19

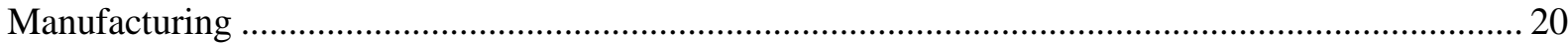

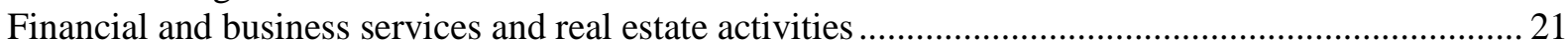

Austria's attractiveness as a regional base for multinationals needs to be maintained ............................ 22

Policies can help maximise the benefits, and lower the adjustment costs, of regional integration........... 22

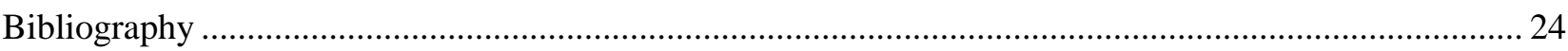

\section{Tables}

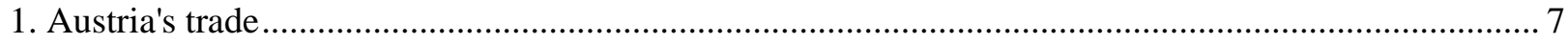

2. Austria: composition of exports of goods to Central and Eastern Europe ……................................... 10

3. Austria: composition of imports of goods from Central and Eastern Europe ...................................... 11

4. Austria: inflows of foreign population by country of origin ............................................................. 15

5. Macroeconomic studies of the effects on Austria of Eastern European integration

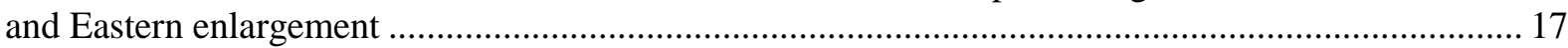

6. Austria: Shift-share analysis of average labour productivity growth, 1995-2004 ............................... 19

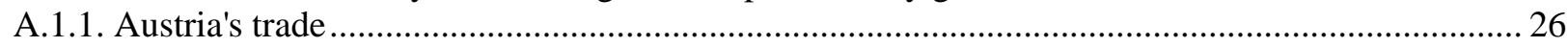

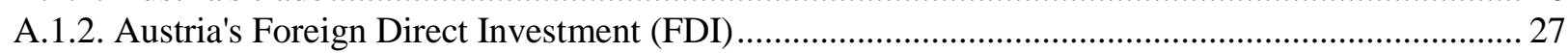

A.1.3. Austria: structure of stock of Foreign Direct Investment in Central and Eastern Europe .............. 28

\section{Figures}

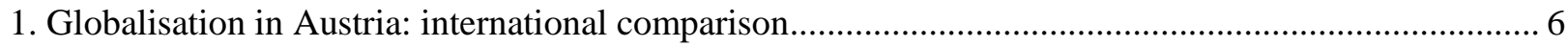

2. Austria's exports to Central and Eastern Europe ….............................................................................. 7

3. Austria's imports from Central and Eastern Europe …….................................................................... 8

4. Importance to Austrian economy of trade with Central and Eastern Europe ......................................... 9

5. Austria trade and FDI with Central and Eastern Europe (CEEC19) ................................................ 12

6. Austria-stock of outward FDI in Central and Eastern Europe ..................................................... 12

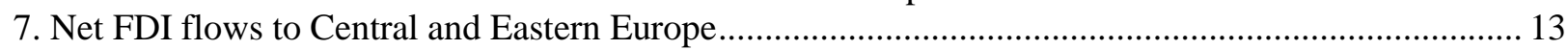

8. Sectoral composition of Austria's stock of FDI in Central and Eastern Europe..................................... 14

9. Immigration flows to Austria from Central and Eastern Europe ...................................................... 15 


\section{ECO/WKP(2007)32}

\section{Boxes}

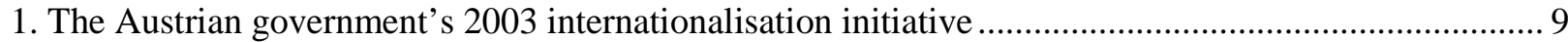

2. Austria: labour productivity developments by sector, 1995-2004 ................................................. 19 
ECO/WKP(2007)32

\title{
AUSTRIA'S DEEPENING ECONOMIC INTEGRATION WITH CENTRAL AND EASTERN EUROPE
}

\author{
by \\ Rina Bhattacharya ${ }^{1}$
}

1. Austria has had to cope with major changes in the international economic environment over the past decade and a half, in particular in its economic relations with its European neighbours. The accession of Austria, Finland and Sweden to the European Union in 1995 and the launching of Economic and Monetary Union (EMU) in 1999 both opened up new trade and investment opportunities for Austrian firms while at the same time subjecting them to increasing global competition. Concurrently, with the disintegration of Communism and the opening up of Central and Eastern Europe in the early 1990s, together with German unification in 1990, Austria's economic ties with Central and Eastern Europe have been growing rapidly. Consequently Austria has been confronted with radical changes in its international environment since 1989, which has had an impact on domestic economic outcomes and policies in a number of key areas.

2. The opening up of Austria's economy over the past few decades has been impressive, as illustrated by the economic globalization index compiled by the Swiss Institute for Business Cycle Research $(K O F, 2007)$. This index attempts to capture the flows of goods, capital (portfolio and foreign direct investment) and services (income payments to foreign nationals) across countries, as well as the degree of restrictions on capital and trade flows. Measured from a scale of 1-100, with a higher number reflecting greater globalization, the KOF economic liberalization index for Austria increased from a value of around 51 in 1970 to over 88 by 2004. In terms of ranking, Austria moved from being the $29^{\text {th }}$ most globalised economy out of 97 in 1970 , to $22^{\text {nd }}$ position out of 99 countries in 1985 , and to $7^{\text {th }}$ position out of 109 countries in 2004. Not only did Austria successfully climb up the globalization ladder over this period, but its economic globalization index rose from a value that was well below the EU15 average, and somewhat below the OECD average, in the early 1970s to one noticeably above the EU15 and OECD averages by 2004 (Figure 1). In short, over the past few decades Austria appears to have experienced a greater increase in its degree of openness to the world economy than many other economically advanced countries, including member countries of the EU15 and the OECD.

1. The author is an economist in the Economics Department at the OECD. This paper draws on material originally produced for the OECD Economic Survey of Austria published in July 2007 under the responsibility of the Economic and Development Review Committee. The author would like to thank Mr. Konrad Pesendorfer from the Austrian Delegation at the OECD, as well as experts from the Austrian Central Bank, the Federal Ministry of Economics and Labour (BMWA), the Austrian Federal Economic Chamber (WKÖ) and the Austrian Institute of Economic Research (WIFO) for comments and assistance in preparing the paper. She would also like to thank OECD colleagues Andrew Dean, Val Koromzay, Andreas Wörgötter, Willi Leibfritz and in particular Rauf Gönenç for comments and contributions on earlier drafts, as well as Roselyne Jamin for technical assistance and Nadine Dufour and Sylvie Ricordeau for technical preparation. 
Figure 1. Globalisation in Austria: international comparison

KOF Economic Globalisation Index

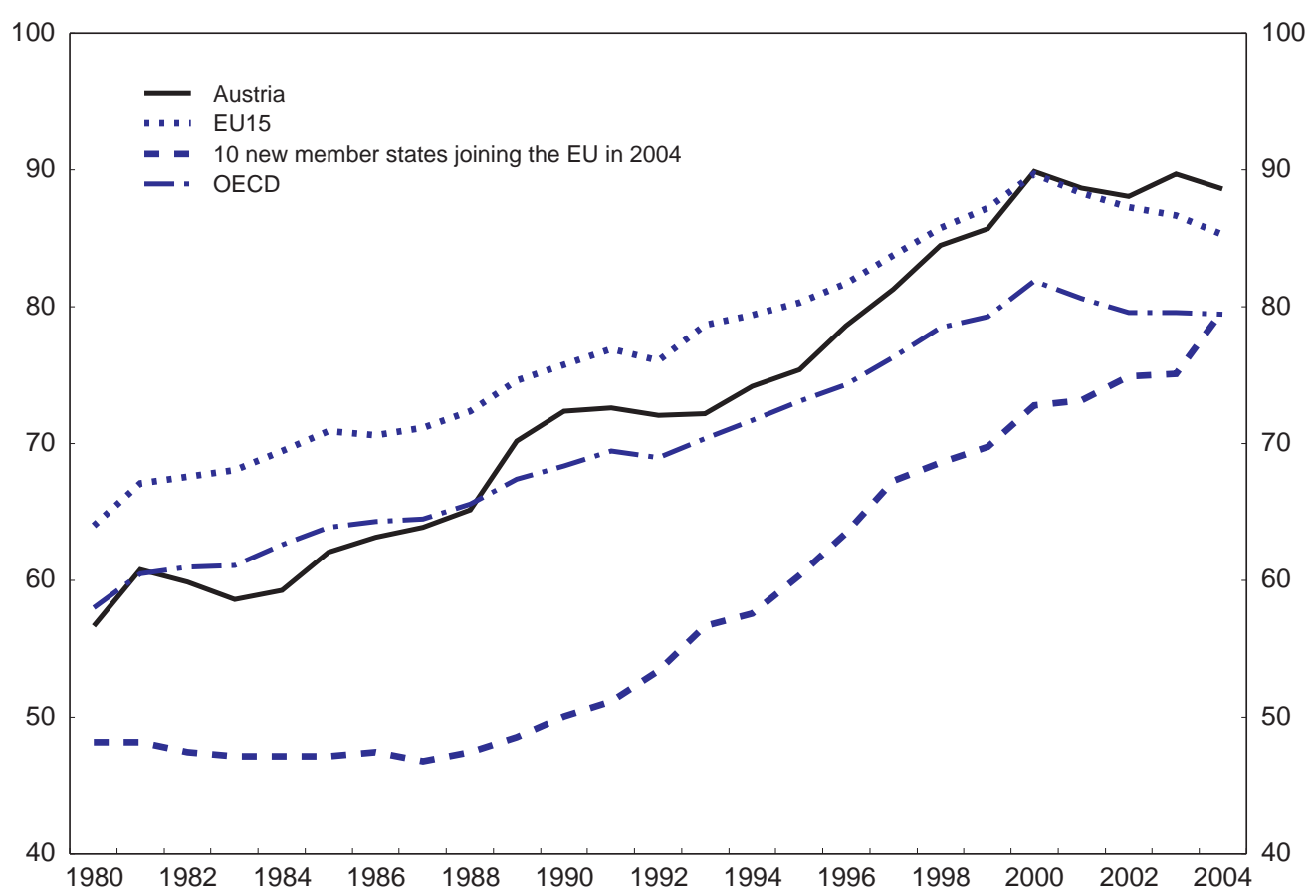

Source: Swiss Institute for Business Cycle Research (KOF).

3. Against this background, this paper focuses on analyzing the effects that economic integration with Central and Eastern European countries (CEECs) have had on the Austrian economy, with a focus on labour market developments, business profitability and competitiveness.

\section{Growing economic integration with Central and Eastern Europe}

\section{Trade links with CEECs have been growing rapidly...}

4. Austria took advantage of the opening up to Central and Eastern Europe to expand its trade ties with the region. Over the period 1991-2005 Austria's exports of goods to the CEEC19 countries grew by $11 \frac{1 / 2}{2}$ per cent per annum on average at constant prices while its total exports of goods grew on average by $7 \%$ a year. $^{2}$ As a consequence the CEEC19's share of Austria's total exports rose from 121/2 per cent in 1991-95 to 18\% in 2001-05 (Figure 2, Table 1 and Annex Table A.1). Export growth was particularly strong during the second half of the 1990s.

2. The CEEC19 include the CEEC5 (the Czech Republic, Hungary, Poland, the Slovak Republic and Slovenia) and the CEEC14 (Albania, Belarus, Bosnia, Bulgaria, Croatia, Estonia, Latvia, Lithuania, Macedonia, Moldova, Romania, Russia, Serbia-Montenegro and Ukraine). 
Figure 2. Austria's exports to Central and Eastern Europe

As per cent of total exports of goods

$\%$

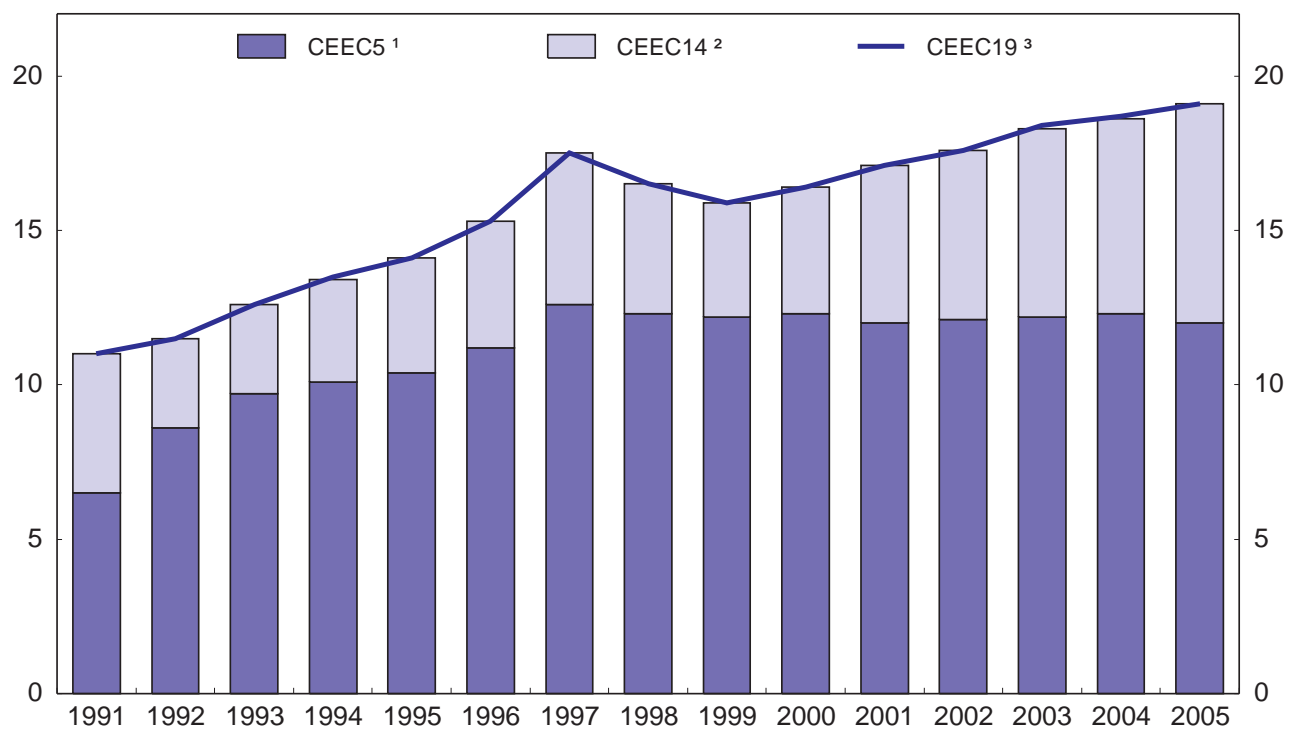

1. CEEC5 is for Czech Republic, Hungary, Poland, Slovak Republic and Slovenia.

2. CEEC14 is for Albania, Belarus, Bosnia, Bulgaria, Croatia, Estonia, Latvia, Lithuania, Macedonia, Moldova, Romania, Russia, Serbia-Montenegro and Ukraine.

3. CEEC19 = CEEC5 plus CEEC14.

Source: Statistics Austria.

Table 1. Austria's trade

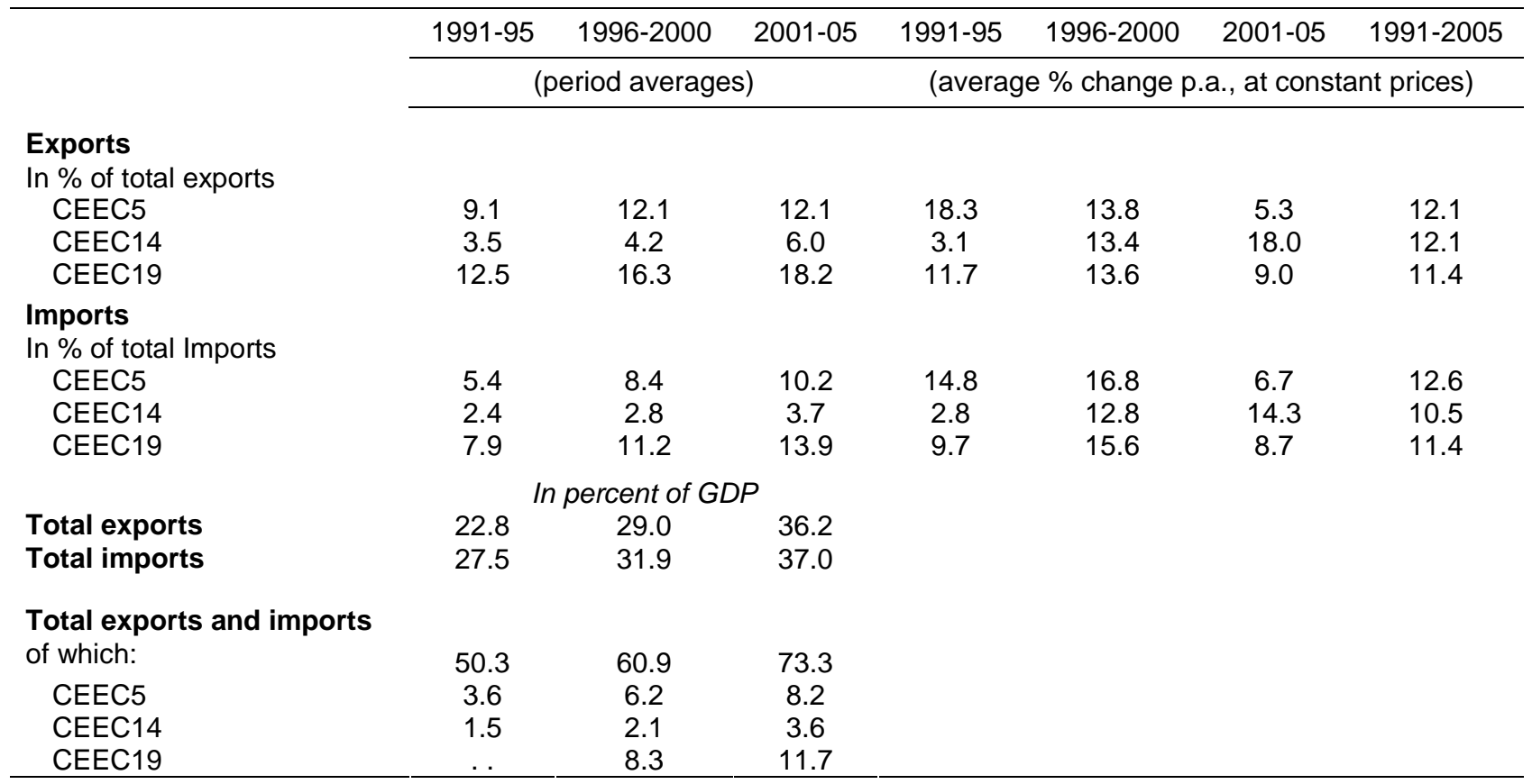

CEEC5: Czech Republic, Hungary, Poland, Slovak Republic, Slovenia.

CEEC14: Albania, Belarus, Bosnia, Bulgaria, Croatia, Estonia, Latvia, Lithuania, Macedonia, Moldova, Romania, Russia, SerbiaMontenegro, Ukraine.

CEEC19: CEEC5 plus CEEC14.

Source: Statistics Austria. 
5. The import side shows a similar pattern, with Austria's imports of goods from the CEEC19 countries also growing by $11 \frac{1}{2}$ per cent per annum on average at constant prices over the period 1991-2005 - substantially higher than the growth of total imports of goods, which averaged 51/2 per cent per annum. As a consequence the CEEC19's share of Austria's total imports increased from $8 \%$ in 1991-95 to 14\% in 2001-05 (Figure 3, Table 1 and Annex Table A.1). Import growth also accelerated sharply during the second half of the 1990s.

\section{Figure 3. Austria's imports from Central and Eastern Europe}

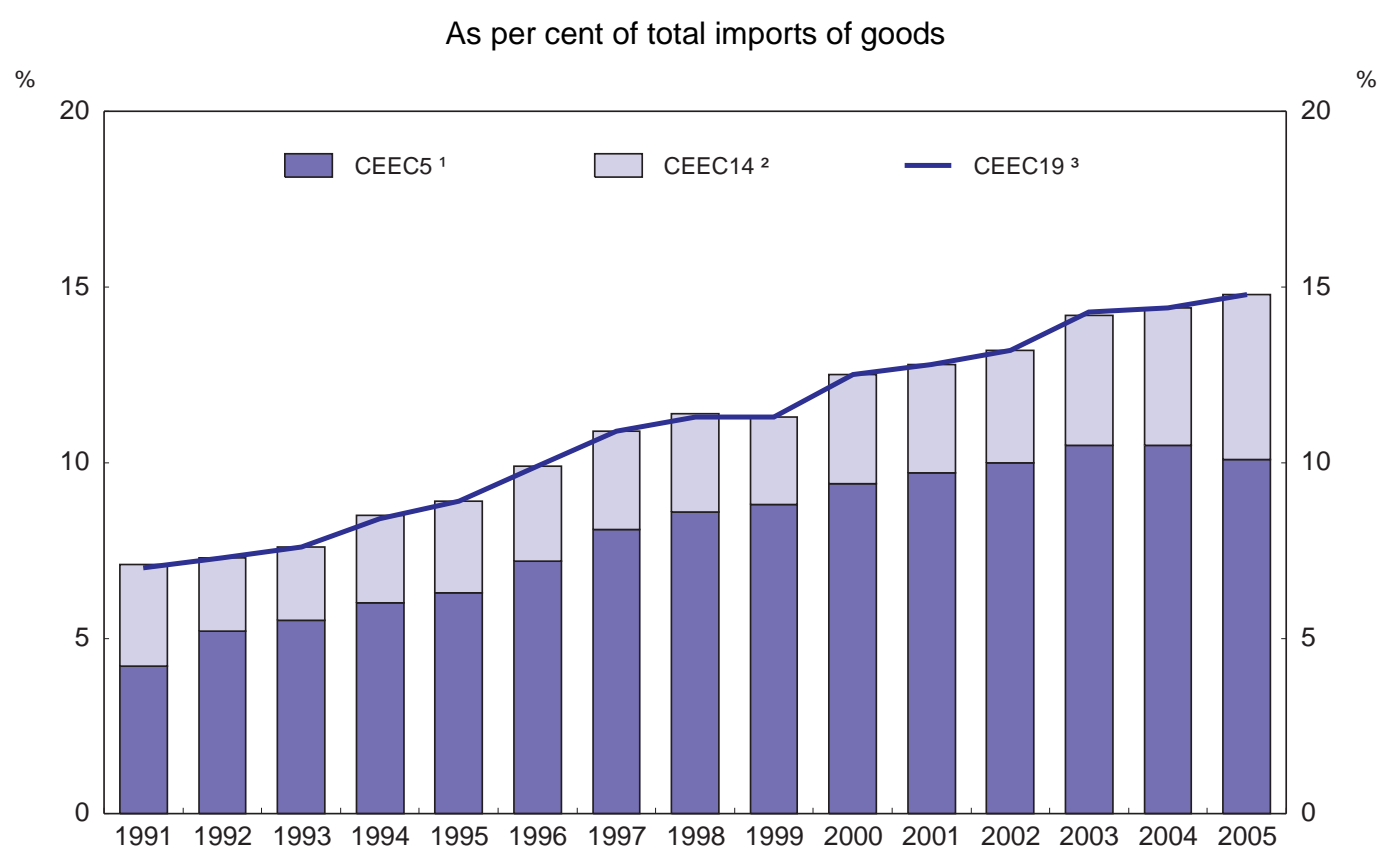

1. CEEC5 is for Czech Republic, Hungary, Poland, Slovak Republic and Slovenia.

2. CEEC14 is for Albania, Belarus, Bosnia, Bulgaria, Croatia, Estonia, Latvia, Lithuania, Macedonia, Moldova, Romania, Russia, Serbia-Montenegro and Ukraine.

3. CEEC19 = CEEC5 plus CEEC14.

Source: Statistics Austria.

6. While undoubtedly impressive, the growth in trade links with the CEEC19 countries started from a very low base at a time when the Austrian economy was opening up at a very rapid pace, boosted by the government's 2003 "internationalization initiative" (Box 1). Thus the contribution of the CEECs to Austria's increasing trade openness was relatively modest - while the share of total exports and imports of goods in Austria's GDP rose by 25 percentage points during 1991-2005, trade with the CEEC19 countries increased by only $81 / 2$ percentage points of GDP (Figure 4 ). 


\section{Box 1. The Austrian government's 2003 internationalisation initiative}

In 2003 an internationalisation initiative "Go International" was jointly launched by the Federal Ministry for Economy and Labour (BMWA) and the Austrian Federal Economic Chamber (WKÖ), in order to increase the competitiveness of Austrian businesses. Altogether $€ 50$ million of additional finance were earmarked for this initiative, and a Strategy Unit for Foreign Trade and Investment was set up at the BMWA. The internationalisation initiative reinforces and partly broadens existing instruments. It includes a comprehensive package of more than 30 measures across departments and institutions - designed to raise awareness, transfer knowledge and promote the creation of business networks. The WKÖ handles the implementation of the bulk of these measures.

Key instruments for promoting Austrian exports and foreign direct investment include trade fairs and market information meetings focused on specific industrial sectors; co-financing of counselling for FDI projects; provision of an efficient and internationally competitive export financing system; and establishment and maintenance of a B2B contact platform. The co-financing of practical training abroad and trainee programmes in export-oriented enterprises, as well as promotion of in-company training programmes with a special focus on external economic relations, are other core elements of the internationalisation initiative. Another key component of this initiative is the co-financing of company and sector-specific market development studies whose focus is on the identification of projects, feasibility assessment of these projects, and evaluation of particular aspects of these projects such as their environmental and employment effects; a total of $€ 2$ million was made available for co-financing of these studies for the period 2004 to 2006 . Special emphasis is given to assistance for first time exporters and measures to promote the image of Austria as an attractive business location. By end-2006 the WKÖ had organised some 600 events as part of this initiative, and an additional 18 marketing offices had been established in areas of interest to the Austrian export sector.

"Go International" and similar earlier initiatives seem to have been successful in addressing some of the structural problems of Austrian exporters and have, for example, contributed to a threefold increase in the number of Austrian exporting companies over the past decade. Originally planned to expire in 2006, "Go International" has been extended until the end of 2007, and a further extension until 2008 is under consideration.

Figure 4. Importance to Austrian economy of trade with Central and Eastern Europe

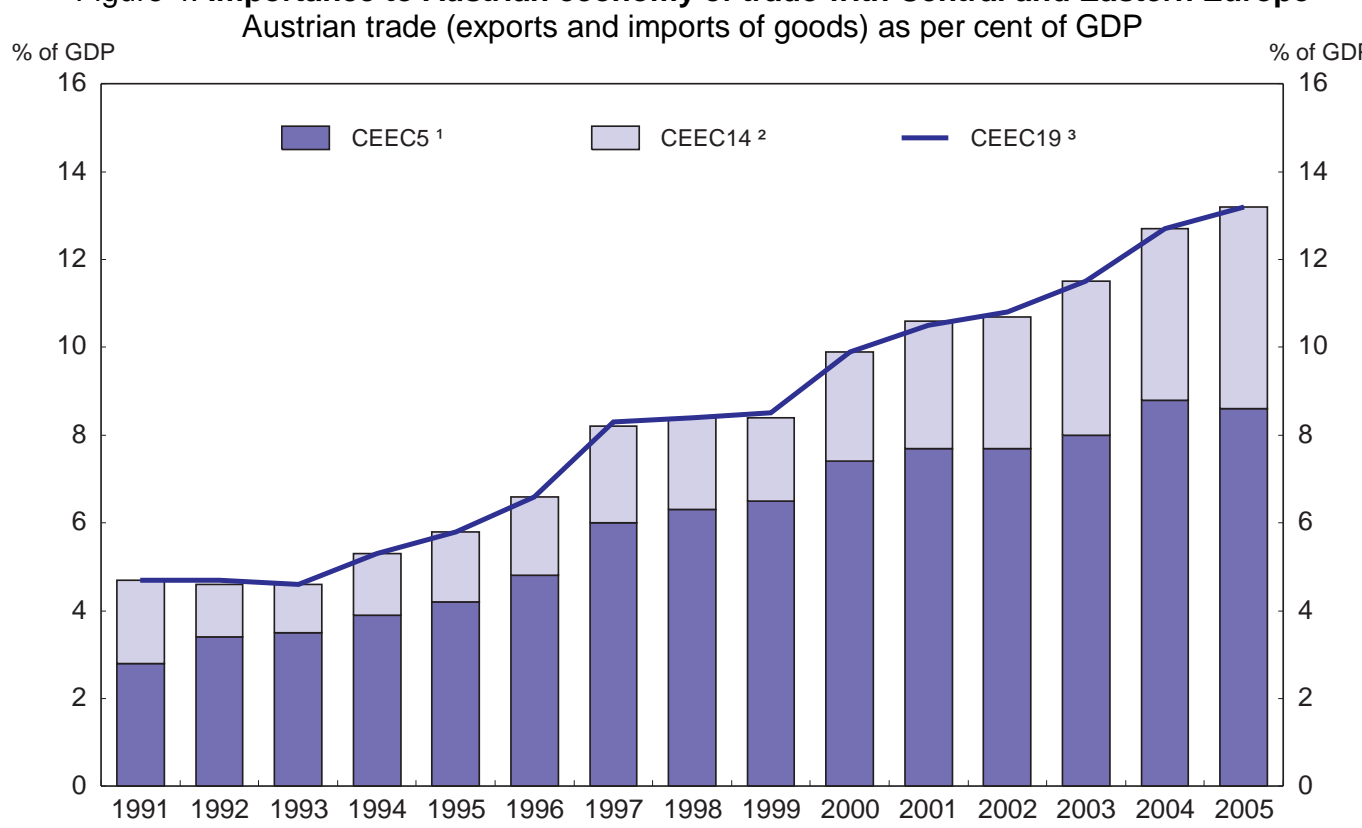

1. CEEC5 is for Czech Republic, Hungary, Poland, Slovak Republic and Slovenia.

2. CEEC14 is for Albania, Belarus, Bosnia, Bulgaria, Croatia, Estonia, Latvia, Lithuania, Macedonia, Moldova, Romania, Russia, Serbia-Montenegro and Ukraine.

3. CEEC19 = CEEC5 plus CEEC14.

Source: Statistics Austria. 
7. The commodity composition of exports of goods to, and imports of goods from, the CEEC5 countries, Bulgaria and Romania has not witnessed any dramatic shifts over the past decade or so (Tables 2 and 3). What is noticeable, however, is that the share in exports of what may regarded as low value-added products - such as agriculture and forestry, food products and beverages, textiles and apparel - has declined, while the share of higher value-added products has increased correspondingly. The same is true of imports. This shift in the composition of trade is consistent with the expansion of outsourcing activities in the manufacturing sector and the growth of intra-industry trade with Central and Eastern Europe.

Table 2. Austria: composition of exports of goods to Central and Eastern Europe

\begin{tabular}{|c|c|c|c|c|c|}
\hline & \multicolumn{2}{|c|}{$\begin{array}{l}\text { Total exports, } \\
\text { EUR million }\end{array}$} & \multirow{2}{*}{$\begin{array}{l}\text { \% change } \\
1996-2005 \\
\end{array}$} & \multicolumn{2}{|c|}{$\%$ Share of Tota } \\
\hline & 1996 & 2005 & & 1996 & 2005 \\
\hline Agriculture, hunting and forestry & 59 & 86 & 44.9 & 1.1 & 0.6 \\
\hline Fishing & 0 & 0 & 160.0 & 0.0 & 0.0 \\
\hline Manufacturing & 5214 & 12972 & 148.8 & 97.7 & 97.7 \\
\hline of which: & & & & & \\
\hline Food products and beverages & 253 & 584 & 131.2 & 4.7 & 4.4 \\
\hline Tobacco products & 14 & 60 & 313.3 & 0.3 & 0.4 \\
\hline Textiles & 198 & 312 & 57.7 & 3.7 & 2.3 \\
\hline Wearing apparel, dressing and dyeing of fur & 118 & 245 & 107.2 & 2.2 & 1.8 \\
\hline Leather, leather products and footwear & 85 & 213 & 150.0 & 1.6 & 1.6 \\
\hline Wood and products of wood and cork & 77 & 281 & 265.8 & 1.4 & 2.1 \\
\hline Paper and paper products, publishing and printing & 366 & 606 & 65.6 & 6.9 & 4.6 \\
\hline Coke, refined petroleum products and nuclear fuel & 200 & 812 & 305.6 & 3.8 & 6.1 \\
\hline Chemicals and chemical products & 574 & 1,331 & 131.9 & 10.8 & 10.0 \\
\hline Rubber and plastics products & 333 & 827 & 148.4 & 6.2 & 6.2 \\
\hline Other non-metallic mineral products & 122 & 244 & 99.4 & 2.3 & 1.8 \\
\hline Basic metals and fabricated metal products & 543 & 1663 & 206.3 & 10.2 & 12.5 \\
\hline Machinery and equipment, n.e.c. & 779 & 1713 & 119.8 & 14.6 & 12.9 \\
\hline Office, accounting and computing machinery & 119 & 331 & 176.9 & 2.2 & 2.5 \\
\hline Electrical machinery and apparatus, n.e.c & 321 & 946 & 195.0 & 6.0 & 7.1 \\
\hline Radio, television and communication equipment & 363 & 982 & 170.6 & 6.8 & 7.4 \\
\hline Medical, precision and optical instruments, watches and clocks & 149 & 264 & 77.8 & 2.8 & 2.0 \\
\hline Motor vehicles and transport equipment & 489 & 1211 & 147.6 & 9.2 & 9.1 \\
\hline Furniture; manufacturing n.e.c. & 111 & 346 & 213.2 & 2.1 & 2.6 \\
\hline Total Exports & 5337 & 13279 & 148.8 & 100.0 & 100.0 \\
\hline
\end{tabular}

1. Bulgaria, Czech Republic, Hungary, Poland, Romania, Slovak Republic, Slovenia.

Source: Austrian National Authorities. 
ECO/WKP(2007)32

Table 3. Austria: composition of imports of goods from Central and Eastern Europe

\begin{tabular}{|c|c|c|c|c|c|}
\hline & \multicolumn{2}{|c|}{$\begin{array}{l}\text { Total imports, } \\
\text { EUR million }\end{array}$} & \multirow{2}{*}{$\begin{array}{l}\% \text { change } \\
1996-2005 \\
\end{array}$} & \multicolumn{2}{|c|}{$\%$ share of total } \\
\hline & 1996 & 2005 & & 1996 & 2005 \\
\hline Agriculture, hunting and forestry & 205 & 461 & 125.4 & 5.2 & 4.3 \\
\hline Fishing & 1 & 2 & 11.1 & 0.0 & 0.0 \\
\hline Manufacturing & 3416 & 9739 & 185.1 & 86.6 & 90.9 \\
\hline \multicolumn{6}{|l|}{ of which: } \\
\hline Food products and beverages & 133 & 500 & 274.9 & 3.4 & 4.7 \\
\hline Tobacco products & 0 & 1 & & 0.0 & 0.0 \\
\hline Textiles & 122 & 188 & 54.3 & 3.1 & 1.8 \\
\hline Wearing apparel, dressing and dyeing of fur & 259 & 418 & 61.3 & 6.6 & 3.9 \\
\hline Leather, leather products and footwear & 76 & 189 & 148.9 & 1.9 & 1.8 \\
\hline Wood and products of wood and cork & 190 & 305 & 60.9 & 4.8 & 2.9 \\
\hline Paper and paper products, publishing and printing & 87 & 271 & 210.6 & 2.2 & 2.5 \\
\hline Coke, refined petroleum products and nuclear fuel & 301 & 1263 & 319.7 & 7.6 & 11.8 \\
\hline Chemicals and chemical products & 225 & 435 & 93.7 & 5.7 & 4.1 \\
\hline Rubber and plastics products & 127 & 339 & 166.3 & 3.2 & 3.2 \\
\hline Other non-metallic mineral products & 127 & 210 & 65.5 & 3.2 & 2.0 \\
\hline Basic metals and fabricated metal products & 512 & 1375 & 168.4 & 13.0 & 12.8 \\
\hline Machinery and equipment, n.e.c. & 312 & 1008 & 223.1 & 7.9 & 9.4 \\
\hline Office, accounting and computing machinery & 12 & 228 & 1791.0 & 0.3 & 2.1 \\
\hline Electrical machinery and apparatus, n.e.c & 279 & 1016 & 263.7 & 7.1 & 9.5 \\
\hline Radio, television and communication equipment & 263 & 239 & -9.1 & 6.7 & 2.2 \\
\hline Medical, precision and optical instruments, watches and clocks & 23 & 88 & 278.3 & 0.6 & 0.8 \\
\hline Motor vehicles and transport equipment & 186 & 1120 & 501.0 & 4.7 & 10.5 \\
\hline Furniture; manufacturing n.e.c. & 181 & 545 & 201.0 & 4.6 & 5.1 \\
\hline Total Imports & 3944 & 10708 & 171.5 & 100.0 & 100.0 \\
\hline
\end{tabular}

1. Bulgaria, Czech Republic, Hungary, Poland, Romania, Slovak Republic, Slovenia.

Source: Austrian National Authorities.

but more striking has been the expansion of Austria's foreign direct investment in CEECs...

8. The growth in Austria's trade links with Central and Eastern Europe over the past decade and a half is indeed noteworthy. But perhaps even more striking has been the expansion of Austria's direct investment activities in the region. While Austria's trade with the CEEC19 countries almost tripled as a share of GDP during 1991-2005 (albeit from a very low base), there was a more than eightfold increase in the GDP share of net foreign direct investment (FDI) flows to the region (though starting from an even lower base). As a result Austria's stock of FDI in the CEEC19 showed a notable increase over the same period, rising from 1\% to 7\% of GDP (Figure 5 and Annex Table A.2). As a reflection of this the region's share in Austria's total stock of FDI more than doubled and its share in Austria's total net FDI flows also increased substantially, averaging around 70\% in 2001-04 (Figures 6 and 7). 
Figure 5. Austria trade and FDI with Central and Eastern Europe (CEEC191)

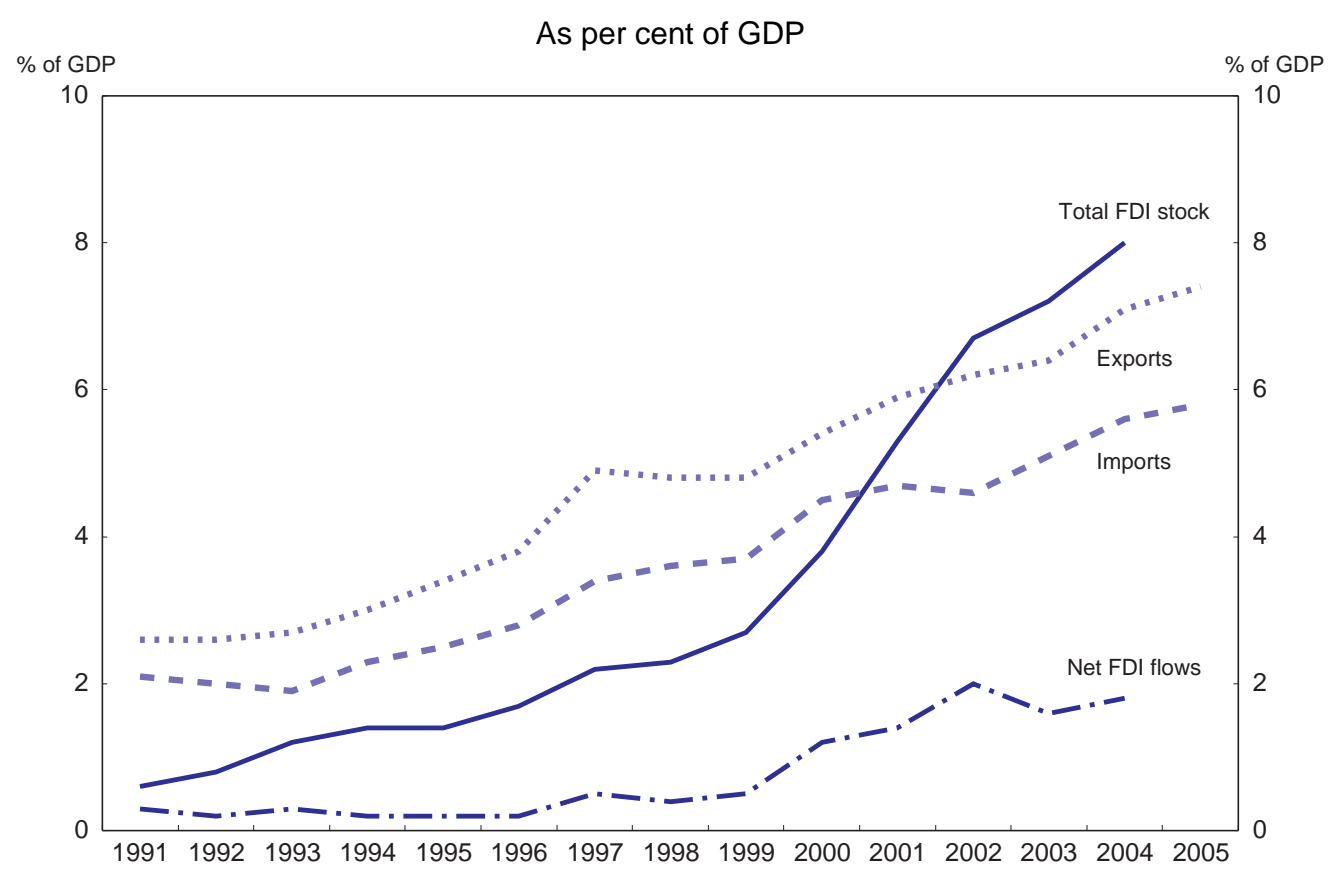

1. CEEC19 is for Czech Republic, Hungary, Poland, Slovak Republic, Slovenia, Albania, Belarus, Bosnia, Bulgaria, Croatia, Estonia, Latvia, Lithuania, Macedonia, Moldova, Romania, Russia, Serbia-Montenegro and Ukraine.

Source: Statistics Austria, Austrian National Bank (OeNB).

Figure 6. Austria-stock of outward FDI in Central and Eastern Europe

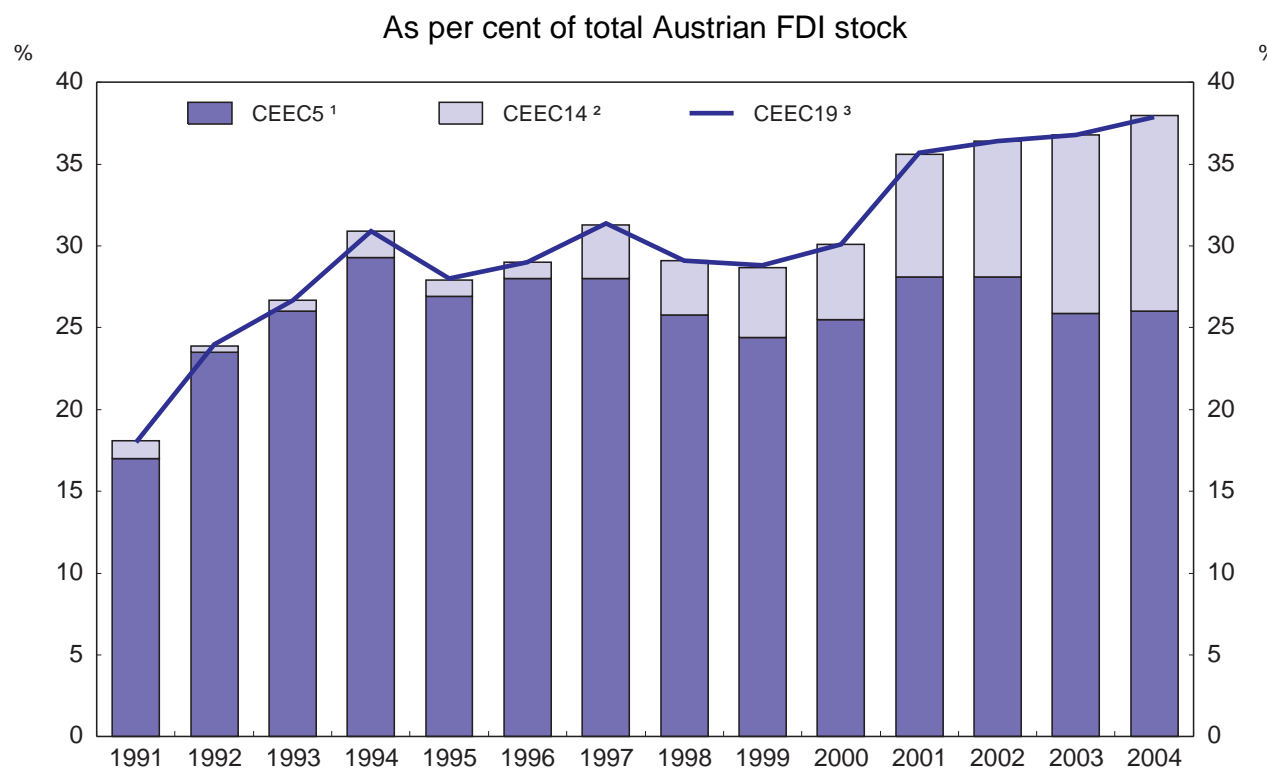

1. CEEC5 is for Czech Republic, Hungary, Poland, Slovak Republic and Slovenia.

2. CEEC14 is for Albania, Belarus, Bosnia, Bulgaria, Croatia, Estonia, Latvia, Lithuania, Macedonia, Moldova, Romania, Russia, Serbia-Montenegro and Ukraine.

3. $\mathrm{CEEC19}=$ CEEC5 plus CEEC14.

Source: Statistics Austria, Austrian National Bank (OeNB). 
Figure 7. Net FDI flows to Central and Eastern Europe

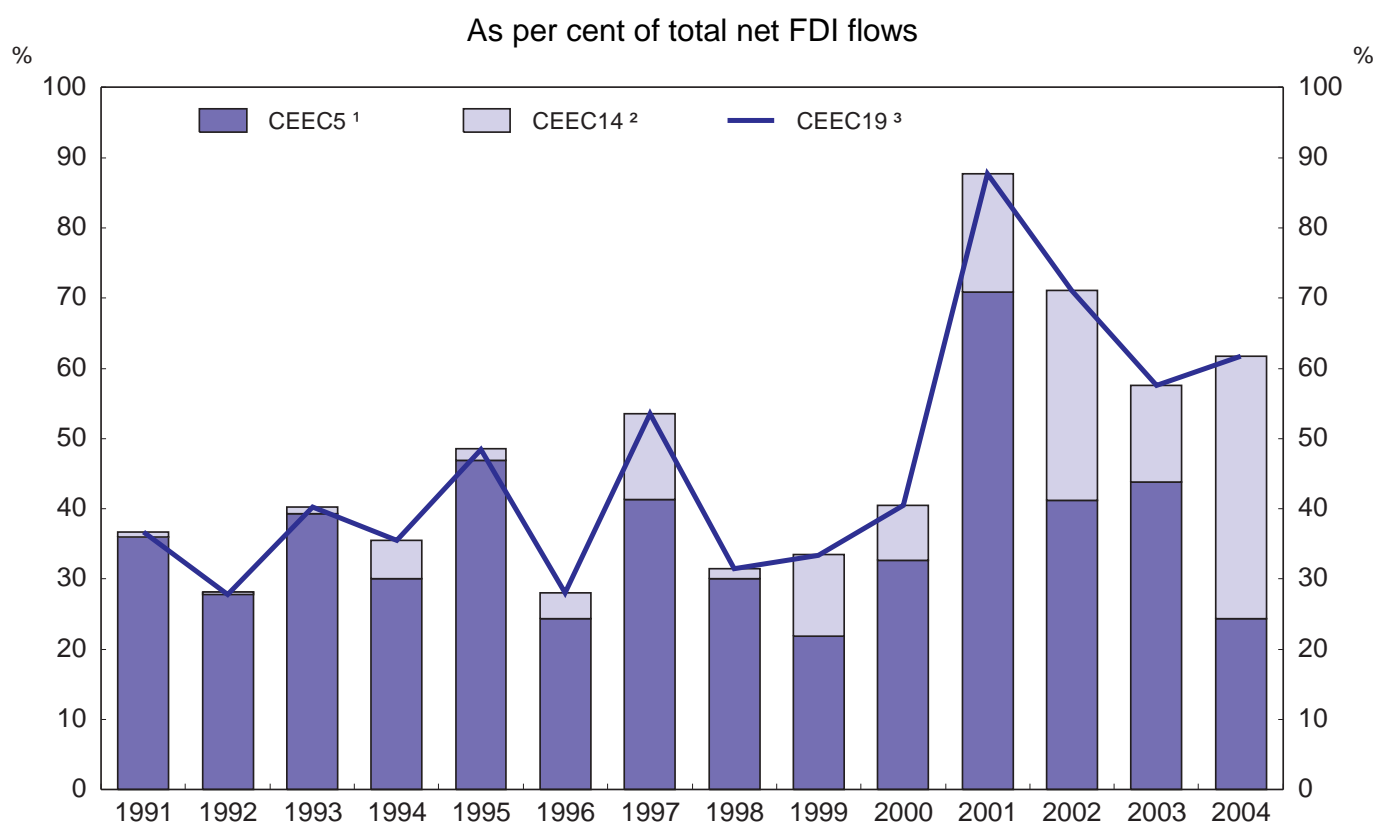

1. CEEC5 is for Czech Republic, Hungary, Poland, Slovak Republic and Slovenia.

2. CEEC14 is for Albania, Belarus, Bosnia, Bulgaria, Croatia, Estonia, Latvia, Lithuania, Macedonia, Moldova, Romania, Russia, Serbia-Montenegro and Ukraine.

3. $\mathrm{CEEC19}=\mathrm{CEEC} 5$ plus CEEC14.

Source: Statistics Austria, Austrian National Bank (OeNB).

9. There has also been a noticeable change in the allocation of Austria's FDI within the region over this period. Prior to 1997, the bulk of Austria's FDI in the CEEC19 countries went to its immediate neighbours, the CEEC5 countries, whereas from 1997 onwards the CEEC14 countries have been significantly increasing their share of Austria's total net FDI flows to the CEEC19 region. Austria started its eastward FDI expansion in 1989, first in Hungary and then in the three other neighbouring countries the Czech Republic, Slovenia and the Slovak Republic. However, from 1997 onwards, first Poland became an important host country for Austrian firms and then several countries within the CEEC14 became much more important, in particular Croatia, Romania, Bulgaria and Russia (Altzinger, 2005). Thus, while the CEEC5 countries accounted for $87 \%$ of net FDI flows to the CEEC19 and over 96\% of Austria's total FDI stock in the region in 1996, these shares fell to $40 \%$ and 68\% respectively by 2004 .

10. Not only has there been a noticeable change in the allocation of Austria's outward FDI within the Central and Eastern European region since the mid-1990s, but its sectoral composition has also evolved in a significant way (Figure 8 and Annex Table A.3). More specifically, the share of manufacturing in the stock of FDI in the CEEC5 countries declined from just under 40\% in 1996 to under 25\% in 2004, with a corresponding increase in the importance of the service sectors. Particularly striking has been the increase in the share of financial intermediation (from $21 \%$ to $47 \%$ of the total stock) and of real estate and business services (from $8 \%$ to $14 \%$ of the total stock) over the same period. This hints at a shift in the main motivation for Austrian FDI in the CEECs from cost minimisation and outsourcing to exploitation of new market opportunities. 
Figure 8. Sectoral composition of Austria's stock of FDI in Central and Eastern Europe 1

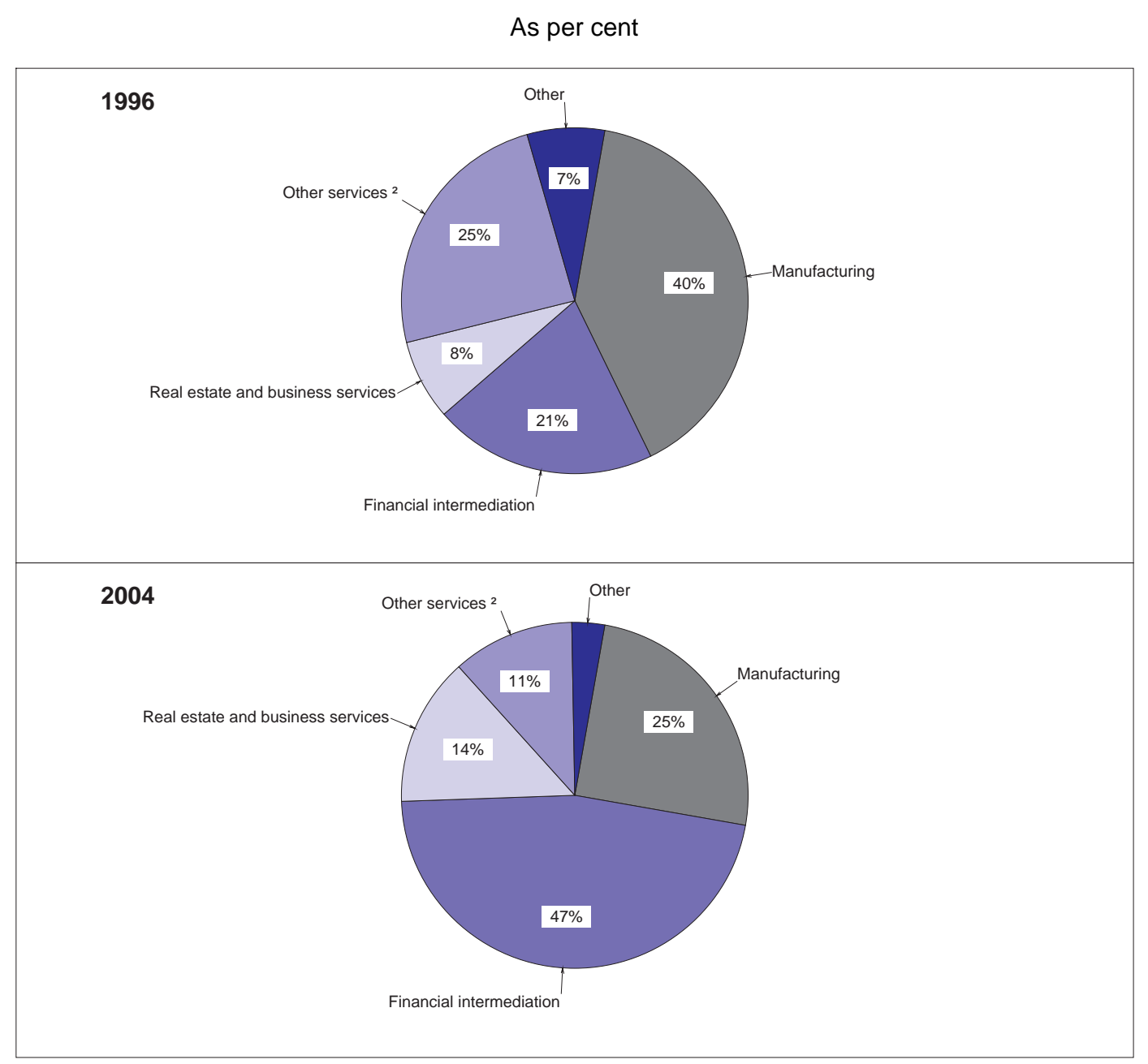

1. CEEC5 is for Czech Republic, Hungary, Poland, Slovak Republic and Slovenia.

2. Wholesale and retail trade, repairs; hotels and restaurants; transport and communication; public administration, other services.

Source: Austrian National Bank, OeNB.

... while immigration flows from CEECs have fluctuated considerably from year to year.

11. One of the most politically sensitive issues associated with Austria's increasing economic integration with the CEECs relates to immigration. The absolute number of registered migrants from Central and Eastern Europe has fluctuated considerably from year to year, with only Romania and the Slovak Republic showing a steady increase in the number of legal migrants entering Austria (Figure 9 and Table 4). Between 1998 and 2003 the number of new migrants from the CEEC5 fluctuated at around 10000 per annum, while the share of the CEEC5 in the total inflow of new migrants showed a more-orless steady downward trend. However, in 2004 there was a sharp rise in the number of registered migrants from the CEEC5 to over 15600 . On top of immigration there are many commuting workers from neighbouring countries, coming even from as far as southern parts of Poland. 
Figure 9. Immigration flows to Austria from Central and Eastern Europe ${ }^{1}$

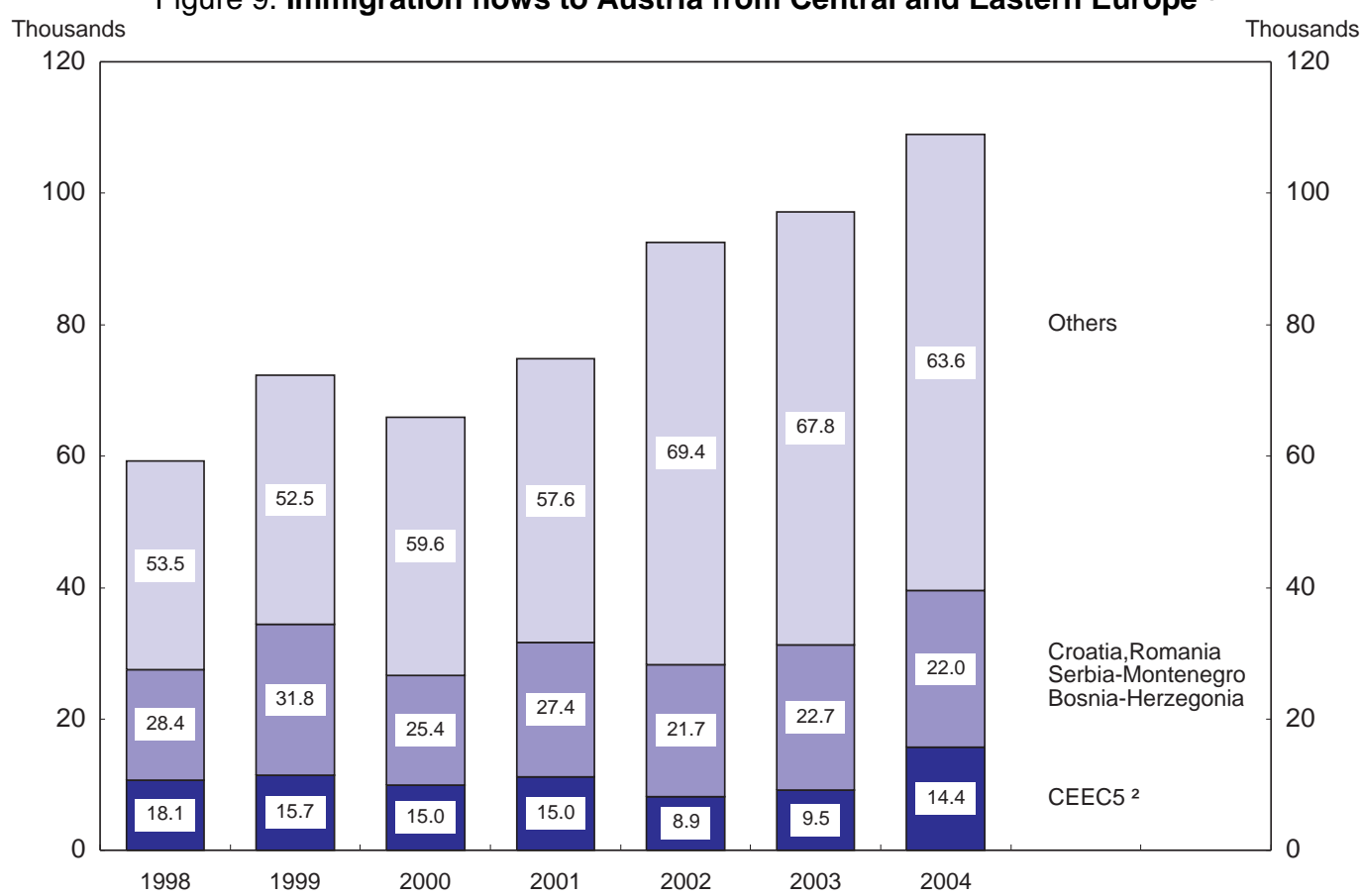

1. Data in the bars refer to per cent of total immigration.

2. CEEC5 is for Czech Republic, Hungary, Poland, Slovak Republic and Slovenia.

Source: Statistics Austria based on data of the Central Registration Register.

Table 4. Austria: inflows of foreign population by country of origin

\begin{tabular}{|c|c|c|c|c|c|c|c|}
\hline & 1998 & 1999 & 2000 & 2001 & 2002 & 2003 & 2004 \\
\hline Europe & 49062 & 59364 & 51740 & 61379 & 59448 & 67766 & 80216 \\
\hline \multicolumn{8}{|l|}{ Of which: } \\
\hline Germany & 6561 & 7459 & 7674 & 10409 & 8303 & 10870 & 13346 \\
\hline Turkey & 5857 & 7208 & 7019 & 7667 & 10360 & 9687 & 7811 \\
\hline Croatia & 2615 & 3887 & 4136 & 6523 & 3110 & 2860 & 2869 \\
\hline Serbia and Montenegro & 9378 & 13483 & 6354 & 6222 & 8754 & 9342 & 10782 \\
\hline Bosnia-Herzegovina & 3287 & 3792 & 4355 & 5360 & 4029 & 4757 & 5019 \\
\hline Poland & 4951 & 5120 & 3499 & 3511 & 2454 & 2899 & 7111 \\
\hline Hungary & 2061 & 2328 & 2534 & 3139 & 2237 & 2517 & 3079 \\
\hline Slovak Republic & 1711 & 1812 & 1919 & 2444 & 2216 & 2318 & 3452 \\
\hline Romania & 1528 & 1834 & 1876 & 2357 & 4158 & 5132 & 5293 \\
\hline Italy & 1239 & 1419 & 1359 & 1710 & 1287 & 1346 & 1399 \\
\hline $\begin{array}{l}\text { Czech Republic } \\
\text { Former Yug. Rep. of }\end{array}$ & 1388 & 1505 & 1425 & 1466 & 956 & 1144 & 1429 \\
\hline Macedonia & 768 & 1025 & 898 & 1392 & 1650 & 1468 & 1502 \\
\hline Slovenia & 636 & 622 & 540 & 650 & 368 & 357 & 589 \\
\hline Africa & 2485 & 2803 & 2838 & 2872 & 3709 & 3930 & 5057 \\
\hline America & 2334 & 2271 & 2312 & 2389 & 2628 & 2901 & 3241 \\
\hline Asia & 4969 & 7535 & 8599 & 7729 & 9914 & 10119 & 10430 \\
\hline Other countries & 379 & 406 & 465 & 417 & 671 & 278 & 303 \\
\hline Unknown & 0 & 0 & 0 & 0 & 16197 & 12170 & 9700 \\
\hline Total & 59229 & 72379 & 65954 & 74786 & 92567 & 97164 & 108947 \\
\hline of which: CEEC5 & 10747 & 11387 & 9917 & 11210 & 8231 & 9235 & 15660 \\
\hline In percent & 18.1 & 15.7 & 15.0 & 15.0 & 8.9 & 9.5 & 14.4 \\
\hline
\end{tabular}

CEEC5: Czech Republic, Hungary, Poland, Slovak Republic, Slovenia.

Source: Statistics Austria based on data of the Central Registration Register. 
12. The share of Central and Eastern Europe in the total inflow of migrants has increased between 2003 and 2006 by $25 \%$, but is still surprisingly low. This may partly be due to the transitional measures of the EU Accession Treaty with regard to immigration from the ten new EU member states. These measures will be reviewed in 2009 and can be extended for a further two years, but from 2011 onwards at the latest Austria will have to open its borders to migrant workers from all EU member states. In this context it is also important to note that these official figures may be somewhat misleading since there are a significant number of illegal migrants from the CEECs working in the informal Austrian economy, the size of which Schneider (2006) has estimated at around 11\% of official GDP in 2002-03. A large share of these unregistered workers from the CEEC work in the 'care' sectors, looking after the elderly for example. ${ }^{3}$

13. The majority of migrants entering Austria are in the medium to low-skill groups. Indeed, among OECD member countries Austria has the lowest share of highly skilled (university graduates) among foreign born residents (OECD, 2004). Biffl (2006) argues that this is partly because the immigration system in Austria has given precedence to family reunification and immigration on humanitarian grounds, while highly skilled people from outside the EU15 are discouraged from joining the workforce. The law provides a special quota regulation for so-called "key workers" (workers who are important for running a company and who earn at least $€ 2300$ per month). This quota, however, is not applied to nationals from the new EU member states and their spouses and children. Nor is it applied to temporary stays of third country nationals, which can often last many years. Given these rather lax entry barriers for skilled migrant workers, their low presence in Austria could be due to: $i$ ) other perceived or real bureaucratic hurdles; ii) difficulties in getting foreign qualifications accredited in Austria; and iii) limited career opportunities for high-skilled workers once they enter the Austrian labour market. Moreover, there has been underinvestment in higher and upper secondary education on the part of second- and third-generation migrants born in Austria. It thus seems that immigration, including from the CEECs, has played a rather limited role in enabling Austria to upgrade the skills of its population and workforce to meet the needs of a dynamic and evolving economy.

\section{Positive overall impact on aggregate output and employment}

\section{Growing regional integration has affected Austria's economy through a multiple of channels.}

14. The rapid expansion of trade with the CEECs is likely to have affected the domestic economy in a number of ways. On the one hand the opening up of new markets provided a stimulus to aggregate domestic demand and employment while opening up new opportunities for profitable investment (trade creation and market expansion effects). On the other hand greater exposure to competition from lower-cost countries may have adversely affected domestic output and employment (competition-induced substitution effect). The relative importance of these two effects for the Austrian economy can only be determined through empirical analysis.

15. The output and employment effects of rapidly growing FDI by Austria in the CEECs manifested themselves through very similar channels (Falk and Wolfmayr, 2005). On the one hand, FDI by Austrian companies generated additional exports and employment for the parent company (for instance of inputs for foreign production of the affiliates, or due to investments in distribution networks, service functions or marketing). More indirectly, relocation of production processes from Austria to CEECs (outsourcing) increased the competitiveness of the end product and thereby secured existing jobs or created additional jobs. On the other hand, the relocation of production to lower cost locations may have substituted for

3. It is estimated that there are between 30000 to 40000 women from Slovakia working illegally in the "care" sector in Austria. 
exports, thereby putting downward pressure on wages and employment. It may also have led to higher unemployment by changing the structure of labour demand (skilled vs. unskilled labour). On this issue as well empirical analysis is needed to determine the aggregate output and employment effects on the domestic economy.

\section{Most empirical studies show a positive overall impact on output and employment.}

16. Indeed, there are a number of empirical studies (Breuss-Schebeck, 1996, Breuss-Schebeck, 1998a) looking into the output and employment effects on Austria of increasing economic integration with the CEECs, most of them using the macroeconomic model of the Austrian Institute of Economic Research WIFO (Table 5). These studies estimate the cumulative positive effect on real GDP growth at around 3.6\% over the period 1989-1997, with employment increasing by $2.6 \%$ or 77000 persons. Simulations using the WIFO model also suggest that the opening up of Eastern Europe and Austria's EU membership in 1995 added about $0.5 \%$ to $1.0 \%$ to average annual economic growth, and that around 100000 to 150000 new jobs could have been created, taking both integration events together, over the period 1989-2004 (Breuss, 2006).

Table 5. Macroeconomic studies of the effects on Austria of Eastern European integration and Eastern enlargement

\begin{tabular}{|c|c|c|c|c|}
\hline & \multirow[t]{2}{*}{ Simulation Horizon } & \multirow{2}{*}{$\frac{\text { Real GDP }}{\%}$} & \multicolumn{2}{|c|}{ Employment } \\
\hline & & & $\%$ & In thousands \\
\hline \multicolumn{5}{|l|}{ Eastern Opening: } \\
\hline \multirow[t]{2}{*}{ Breuss-Schebeck (1998a) } & $1989 / 1997$ & & & \\
\hline & $\begin{array}{l}\text { cumulative } \\
\text { (per year) }\end{array}$ & $\begin{array}{l}3.6 \\
(0.5)\end{array}$ & $\begin{array}{l}2.6 \\
(0.3)\end{array}$ & $\begin{array}{l}76.9 \\
(9.6)\end{array}$ \\
\hline \multirow{3}{*}{$\begin{array}{l}\text { Eastern Opening and EU membership: } \\
\text { Breuss (2006) }\end{array}$} & & & & \\
\hline & $1989 / 2004$ & & & \\
\hline & $\begin{array}{l}\text { cumulative } \\
\text { (per year) }\end{array}$ & $0.5-1.0$ & & $100-150$ \\
\hline \multicolumn{5}{|l|}{ Eastern-Enlargement: } \\
\hline \multirow[t]{2}{*}{ Breuss-Schebeck (1998b) } & $2002 / 2010$ & & & \\
\hline & $\begin{array}{l}\text { cumulative } \\
\text { (per year) }\end{array}$ & $\begin{array}{c}1.3 \\
(0.14)\end{array}$ & $\begin{array}{c}0.8 \\
(0.1)\end{array}$ & $\begin{array}{l}27.5 \\
(3.0)\end{array}$ \\
\hline \multirow{2}{*}{$\begin{array}{l}\text { Breuss } \\
(2001,2002,2005)\end{array}$} & $2001 / 2010$ & & & \\
\hline & cumulative & 0.9 & 0.1 & 3.0 \\
\hline \multirow{3}{*}{ Breuss (2006) } & (per year) & $(0.15)$ & $(0.0)$ & $(0.5)$ \\
\hline & $2004 / 2014$ & & & \\
\hline & per year & 0.2 & & \\
\hline
\end{tabular}

17. Regarding specifically the Eastern enlargement that took place in 2004, econometric studies using the WIFO model (Breuss-Schebeck, 1998b) and Oxford Economic Forecasting OEF model (Breuss, 2001, 2002, 2005) estimate that, as a consequence, Austria's real GDP could increase by a cumulative 0.9 percentage points over the period until 2010 (roughly 0.15 percentage points per year). ${ }^{4}$ The estimated

4. Indeed, Breuss (2006) estimates that Austria can expect to gain more than any of the other older EU states from the EU enlargement of 2004, with annual growth of real GDP higher by around 0.2 percentage points over the next ten years. 
impact on employment, however, varies widely. Simulations using the $O E F$ model suggest a cumulative net addition of 3000 jobs, or an employment increase of $0.1 \%$, over the period 2001-10. By contrast simulations based on the WIFO model estimate a cumulative net increase of $28000 \mathrm{jobs}$, or an employment increase of $0.8 \%$, over the period 2002-10.

\section{Some segments of the population and workforce have been adversely affected}

\section{The effects of foreign direct investment have varied across sectors and skill levels.}

18. Turning now to the output and employment effects of FDI by Austria in the CEECs, the initial empirical studies provided somewhat conflicting results. ${ }^{5}$ More recent empirical analysis, covering the manufacturing sectors in seven EU countries over the period 1995-2000, indicate that imports of intermediate goods from the same industry originating from low-wage countries have a significant and negative impact on employment in the importing countries (Falk and Wolfmayr, 2005). More specifically, rising intermediate imports from low-wage countries may have accounted for an approximate reduction of 0.25 percentage points in employment per year in the seven EU countries. For Austria this would imply a loss of around 2700 jobs per year in the affected manufacturing sectors. Another interesting empirical finding is that the impact on employment of imported materials from low-wage countries is statistically significant in industries with low skill intensity but not in skill-intensive industries such as machinery, electrical, optical and transport equipment.

19. More strikingly, the impact on employment and wages of FDI and outsourcing is estimated to vary considerably across sectors. Employment in the manufacturing sector in Austria has been shrinking, in contrast to the dynamic growth of jobs at foreign affiliates. During 1993-2003 there was a reduction of 73000 manufacturing jobs in the domestic economy at the same time that employment in affiliates of Austrian firms located in the CEEC5 increased by some 60000 . Thus it is not surprising that the results of another recent empirical study point to a substitutive relationship between employment in foreign affiliates and home-based employment in manufacturing, with an estimated elasticity of substitution of $0.5-$ implying that a $1 \%$ increase in wages of home-based workers relative to the wages of workers based abroad results in a $0.5 \%$ decrease in domestic employment (Falk and Wolfmayr, 2006).

20. By contrast, the empirical results for the services sectors show a long-run complementary relationship between domestic employment and employment in foreign affiliates of Austrian firms in the CEEC5. More precisely, the results suggest that ten newly created jobs in the CEEC5 are associated with the creation of half a new job in Austria, and the indirect employment effects are likely to be much higher (Falk and Wolfmayr, 2006). In short, the empirical analysis implies that foreign direct investment activities in the services sectors have an overall positive impact on domestic employment in Austria in the long-run. In the short-run however there is a substitutive relationship, with domestic employment to some extent being substituted by employment in foreign affiliates.

5. Somewhat surprisingly, the first empirical study by Pfaffermayr (2001), covering the period 1990-96, found that job creation by Austrian affiliates in the CEECs is complementary to domestic employment. Using firm-level panel data for a number of European countries Konings and Murphy (2001) found no evidence that FDI in the CEECs caused job losses in the home economy. By contrast, and covering a longer and more recent period, Marin (2004) calculated that 24000 jobs were lost in Austria as a consequence of FDI by Austria in the CEECs since the fall of the iron curtain in 1989. 


\section{Regional integration has given a boost to productivity, competitiveness and profitability}

21. Increasing economic integration with the economies of CEECs could have affected labour productivity in Austria through two main channels. More intensive competition from these economies may have stimulated innovation and productivity growth in those sectors directly and/or indirectly affected by it - an 'intra-industry' productivity effect. It could also have given rise to shifts in labour allocation across sectors with varying levels of labour productivity, with consequences for labour productivity at the aggregate level - a 'resource reallocation' or 'shift' effect. Empirical studies on Austrian outsourcing (relocation of parts of production processes) to the CEECs suggest that it significantly increased total factor productivity, thereby improving the competitiveness of Austrian firms. These studies also indicate that outsourcing changed relative employment demand in favour of the highly skilled (Egger et al. 2001, Kratena and Wüger, 2001).

22. To provide some further insight into the issue Box 2 presents a sectoral shift-share analysis of labour productivity over the period 1995-2004. The results indicate that three sectors have made a particularly significant contribution to aggregate labour productivity growth - the manufacturing sector; wholesale and retail trade, hotels and restaurants, transport and communications; and financial and business services and real estate activities. However, the transmission channels were very different, with intra-industry productivity growth being predominant in manufacturing, and the 'resource reallocation' effect being the key channel in financial and business services and real estate activities. Also, within manufacturing three sub-sectors - coke and refined petroleum products; electrical and optical equipment; and transport equipment - showed particularly strong performance in terms of labour productivity growth.

\section{Box 2. Austria: labour productivity developments by sector, 1995-2004}

A shift-share analysis of labour productivity developments in Austria over the period 1995-2004, using data by sector on numbers of hours worked, provides some interesting insights into the evolution of the Austrian economy over the past decade and a half (Table 6).

Table 6. Austria: Shift-share analysis of average labour productivity growth, 1995-2004

Average percentage change per annum

\begin{tabular}{lcccc}
\hline & \multicolumn{1}{c}{$\begin{array}{c}\text { Average labour } \\
\text { productivity growth }\end{array}$} & \multicolumn{2}{c}{$\begin{array}{c}\text { Contribution to total labour } \\
\text { productivity growth }\end{array}$} \\
\cline { 2 - 5 } & & $\begin{array}{c}\text { "Intra- } \\
\text { industry" }\end{array}$ & "Shift" & Total \\
Agriculture, hunting and forestry & $1.0 \%$ & $0.0 \%$ & $0.0 \%$ & $0.0 \%$ \\
Mining, electricity, gas, and water supply & $6.6 \%$ & $0.2 \%$ & $-0.1 \%$ & $0.1 \%$ \\
Manufacturing & $4.7 \%$ & $1.0 \%$ & $-0.4 \%$ & $0.5 \%$ \\
$\quad \begin{array}{l}\text { Construction } \\
\text { Trade, hotels and restaurants, transport }\end{array}$ & $2.7 \%$ & $0.2 \%$ & $-0.2 \%$ & $0.1 \%$ \\
$\quad$ and communications & $1.9 \%$ & $0.5 \%$ & $0.0 \%$ & $0.5 \%$ \\
$\quad$ Financial and business services and real & & & & $0.5 \%$ \\
$\quad$ estate & $-2.9 \%$ & $-1.1 \%$ & $1.7 \%$ & $0.5 \%$ \\
Total & $1.7 \%$ & $0.8 \%$ & $1.1 \%$ & $1.7 \%$ \\
\hline
\end{tabular}

Source: Organisation for Economic Cooperation and Development (OECD) STAN database and staff calculations.

Overall labour productivity growth over this period averaged $1.7 \%$ per annum. Manufacturing, and financial and business services and real estate activities, were the sectors that contributed the most to this productivity growth, each contributing about $30 \%(0.5$ percentage points) to the total. The broad category of wholesale and retail trade, hotels and restaurants, and transport and communications made a similar contribution to overall productivity growth. This overall contribution is a combination of an "intra-industry" effect (reflecting labour productivity developments within 
each individual sector) and a "shift" effect (reflecting the impact on total labour productivity growth of shifts in labour allocation across sectors with varying levels of labour productivity).

In absolute terms, our estimates suggest that labour productivity growth averaged $-2.9 \%$ in financial and business services and real estate activities over the period 1995-2004. However, the sector made a positive contribution to overall productivity growth because of a shift of labour away from lower-productivity sectors towards this sector. More specifically, labour productivity growth within this sector (the "intra-industry"effect) contributed -1.1 percentage points to total productivity growth, but this was more than offset by a positive "shift" effect through which financial and business services and real estate activities contributed 1.7 percentage points to total labour productivity growth.

The story in the manufacturing sector is the complete opposite. Labour productivity growth in this sector averaged $4.7 \%$ per annum and contributed 1.0 percentage point to the economy's overall labour productivity growth. However, the period 1995-2004 witnessed a shift in labour away from manufacturing towards other lower-productivity sectors, resulting in a labour productivity loss that contributed -0.4 percentage points to overall labour productivity growth. Nevertheless, Austria lost a smaller share of its manufacturing jobs compared to most other OECD countries.

Disaggregated data for the manufacturing sector on hours worked is not available. However, a similar analysis using total employment by manufacturing sub-sector over the period 1991-2004 show that three sub-sectors enjoyed particularly strong intra-sectoral productivity growth:

i. coke and refined petroleum products;

ii. electrical and optical equipment; and

iii. transport equipment.

At the same time a shift of labour away from the manufacture of textile and textile products, and of electrical and optical equipment, towards lower-productivity sectors outside of manufacturing resulted in a loss of labour productivity growth for the overall economy. Disaggregated data for the services sectors is not available to do a similar analysis for real estate, renting and business activities.

\section{Manufacturing}

23. It is difficult to determine the extent to which growing competition from lower-cost CEECs acted as a catalyst and incentive for productivity growth in Austrian manufacturing, and/or facilitated a resource reallocation towards more productive sectors. Nevertheless, the strong growth of both trade and FDI in manufacturing, and the change in the commodity composition of both exports and imports described above, is at least consistent with growing intra-industry trade and FDI with CEECs having enabled the manufacturing sector in Austria to rapidly increase productivity over the past decade.

24. Within this sector it is interesting to note that manufacture of transport equipment, which saw a significantly above-average labour productivity growth rate over the period 1991-2004, also experienced a substantially higher than average growth in imports from the CEECs during 1996-2005. Over the same time periods estimated labour productivity growth in the manufacture of coke and refined petroleum products was also exceptionally high and simultaneously enjoyed significantly higher than average growth in both exports to, and imports from, the CEECs. It would thus not be surprising if expansion of trade with the CEECs had a significant positive effect on productivity growth at least in these two sub-sectors. ${ }^{6}$

6. Nevertheless, within sub-categories of manufacturing an additional complication is the lack of data on hours worked and on export and import price deflators, making it even trickier to reach any definite conclusions on how growing economic integration with the CEECs may be linked with the productivity developments reported in Box 2. 


\section{Financial and business services and real estate activities}

25. The past decade has witnessed a shift in employment share away from lower-productivity sectors towards financial and business services and real estate activities in Austria (even if their share in total employment is still below that in other comparable economically advanced countries). There is no hard evidence or analysis on what factors were behind this. A large part of it probably reflects domestic outsourcing (leasing and contracting out) of services previously carried out in-house by manufacturing firms in Austria. Nevertheless it is plausible to speculate that expansion abroad by Austrian firms may have provided a significant boost to domestic demand in this sector, especially for legal and information technology services and possibly also real estate services - especially given the empirical evidence discussed above of a long-run complementary relationship between domestic employment and employment in foreign affiliates in the services sectors, and the increase in the share of these sectors in the total stock of Austria's FDI in the CEECs.

26. When Austrian firms first started investing in CEECs following the fall of the iron curtain in 1989 they faced a large number of start-up troubles, and the profitability of Austrian affiliates based in the region was rather modest. However, most of these problems have been overcome and current investments are quite profitable, notably the most recent investments in Croatia and Romania. Altzinger (2005) calculates that, in 2003, total annual profits from Austrian affiliates translated into an average rate of return on equity of $4 \%$ for investments in the EU15, 8\% for the CEEC5 and 91/2 per cent for the CEEC14. At the same time he points out that Austrian affiliates in the CEECs re-invested much larger shares of their profits than Austrian affiliates in the EU15, partly because these investments were urgently needed for the tasks of reorganization and restructuring of existing companies. The remarkable profitability of Austrian affiliates in CEECs provides empirical support for the widely held view that the opening up of these economies helped to significantly improve the overall competitiveness and profitability of Austrian firms.

27. This has particularly been the case in financial services. Indeed, as early as 2002 and 2003, steady expansion in the CEECs had a positive impact on the profitability of Austria's consolidated banking sector, as reflected in the far higher profitability of the CEEC operations of Austrian banks in comparison with their domestic business activities. For example, although the CEECs accounted for only some $12 \%$ of the consolidated total assets of Austrian banks at the end of 2003,23\% of their pretax profits was generated in the region (Breyer, 2004). This higher profitability was primarily due to wider margins, lower credit risk costs and cost savings following extensive restructuring measures. Breyer thus argues that significant business exposure in the CEECs is likely to have greatly helped Austrian banks weather the economically difficult years between 2001 and 2003 better than German banks. Given that the pioneer period for banks in these countries is coming to a close and more and more competitors are entering the market, the extraordinarily high profit margins of Austrian banks will be almost certain to decline in the future. Nevertheless, the first mover advantage puts Austrian financial institutions in a very good competitive position.

28. To sum up: general equilibrium studies show that the Austrian economy as a whole has benefited substantially from the expansion of economic ties with Central and Eastern Europe. Indeed, among the older EU member states Austria has benefited the most from the transition of the CEECs from planned economies to market economies, and the subsequent entry into the EU of the ten new member states (mostly from Central and Eastern Europe) in 2004. In particular, the expansion of economic ties with Central and Eastern Europe has provided a significant boost to growth, productivity, competitiveness, profits - and, more controversially, aggregate employment. More disaggregated partial equilibrium studies, however, indicate that some segments of the population and workforce have been adversely affected by Austria's growing economic integration with the CEECs, and in particular low-skilled and semi-skilled workers in the manufacturing sector. 


\section{Austria's attractiveness as a regional base for multinationals needs to be maintained}

29. Regarding inward investment into Austria, there is some evidence to suggest that although Vienna was an obvious base for international companies starting operations in Eastern Europe, certain policy shortcomings and the emergence of new rival locations has weakened its position in recent years. This hypothesis is supported in a recent study by Delia Meth-Cohn (2006) which reports the findings of in-depth interviews conducted during June to October 2005 with ten senior regional executives of large multinationals either currently or formerly based in Vienna. The interviews indicated that Vienna still has a number of important strengths, including: $i$ ) availability of senior management with experience in the region and personal ties to Austria; ii) its attractiveness as a location for expatriates to live in; and iii) proximity by air and road.

30. However, expatriate managers are also somewhat discouraged by various constraints in Vienna which require the attention of policymakers if Austria desires to maintain, or develop further, its position as a central hub for multinationals operating in Central and Eastern Europe. These constraints include bureaucratic delays in getting work permits for non-EU expatriate managers and workers and those from the new EU member states, and lack of rapid road and rail connections (and significant delays in developing them). This is consistent with the findings of an OECD study which argues the case for better transport policy coordination between Austria and the Slovak Republic (OECD, 2003). It is important in this context to note that the Austrian government has been trying to tackle this problem. In June 2004 it announced plans for expanding the motorway network around Vienna, including a connection to the Czech Republic border (not due to be completed before 2013). A motorway link between Vienna and the Slovak capital of Bratislava is due to be completed by the end of 2007. More recently, the government has announced heavy infrastructure investment of $€ 4.6$ billion in roads and $€ 6.4$ billion in railways over the period 2007 to 2010.

31. It also appears to be the case that some rival locations such as Geneva and Bratislava offer more favourable personal income tax regimes and more favourable tax treatment of expatriate perks such as housing, schools and cars. However, this does not seem to be a major factor affecting the locational decisions of multinationals. Furthermore, given the highly favourable corporate tax rate and the recent introduction of corporate group taxation, it would not be advisable at this stage for Austria to offer further tax advantages to expatriate managers and workers of multinational companies.

\section{Policies can help maximise the benefits, and lower the adjustment costs, of regional integration.}

32. As discussed above, although general equilibrium (aggregate) effects have been clearly positive, there are important segments of the population that have been adversely affected by these developments. In particular, several empirical studies have shown that low-skilled and semi-skilled workers in manufacturing have had difficulty coping with the growing competition from the CEECs. A key challenge for policy-makers in Austria is to help them re-integrate into the domestic labour market, notably through active labour market policies and vocational training and re-training programmes. The immigration system in Austria also needs to be reformed in a way that encourages the entry of highly skilled and well-qualified workers that meet the requirements of the domestic labour market. Investing in transport (road and rail) connections with key Central and Eastern European locations - consistent with the new government's plans, as outlined in its 2007 and 2008 budgets - and reducing bureaucratic hurdles and red tape for multinational companies seeking to operate out of Vienna will also be important if Vienna is to maintain its position as a central hub for companies operating in the region. 
33. Supportive government policies can also help to enhance the positive productivity, competitiveness and profitability effects of Austria's growing economic integration with the CEECs. Government policies to promote education and training, R\&D and innovation, plus active labour market policies can all help the Austrian economy to shift to higher value-added activities. In this way the government has a role to play in helping Austrian firms to cope successfully with intensifying competition from the CEECs (and other countries), and to facilitate the development of a complementary specialisation of the Austrian economy with the CEECs. 


\section{BIBLIOGRAPHY}

Altzinger, W. (2005), "Who Gains and Who Loses? On the Earnings of Austrian Affiliates in the new EU Member Countries", Vienna University of Economics and BA, Austria. Paper prepared for a joint workshop, HWWA and WU-Wien, on 'Re-location of production and jobs to CEE countries - who gains and who loses?', Hamburg, Germany, 16th-17th September, 2005.

Biffl, Gudrun (2006), "Conditions of Entry and Residence of Third Country Highly-Skilled Workers in Austria", Austrian Institute of Economic Research (WIFO), Vienna.

Breuss, F. (2001), Makroökonomische Auswirkungen der EU-Erweiterung auf alte und neue Mitglieder“, WIFO-Monatsberichte, 74(11), S. 655-66.

Breuss, F. (2002), “Kosten der Nicht-Erweiterung der EU für Österreich“, WIFO-Studie, Wien, März.

Breuss, F. (2005), "EU-Osterweiterung: Ein Wachstumsimpuls für den gesamten Wirtschaftsraum?“, in: R. Caesar, K. Lammers und H.-E. Scharrer (Hrsg.), Europa auf dem Weg zum wettbewerbsfähigsten und dynamischesten Wirtschaftsraum der Welt? - Eine Zwischenbilanz der Lissabon-Strategie, Nomos-Verlag: Baden-Baden, S. 137-163.

Breuss, F. (2006), "Ostöffnung, EU-Migliedschaft, Euro-Teilnahme und EU-Erweiterung“, WIFO Working Paper 270/2006, Vienna.

Breuss, F and F. Schebeck (1996), "Ostöffnung und Osterweiterung der EU: Ökonomische Auswirkungen auf Österreich“, WIFO-Monatsberichte, 1996, 69(2), S. 139-151, Vienna.

Breuss, F. and F. Schebeck (1998a), "Ostöffnung und Osterweiterung der EU: Eine Neubewertung der ökonomischen Auswirkungen auf Österreich nach der Agenda 2000“, in Palme, G., Schremmer, Ch. (Koordination), Regionale Auswirkungen der EU-Integration der MOEL, Studie des WIFO und des ÖIR im Auftrag der ÖROK, Wien, 1998, S. 23-42.

Breuss, F. and F. Schebeck (1998b), "Kosten und Nutzen der EU-Osterweiterung für Österreich“, WIFOMonatsberichte, 71(11), 1998, S. 741-50.

Breyer, Peter (2004), "Central and Eastern Europe - The Growth Market for Austrian Banks", Monetary Policy \& The Economy, Q3/04.

Egger, P., M. Pfaffermayr and Y. Wolfmayr-Schnitzer (2001), "The International Fragmentation of the Value Added Chain: The Effects of Outsourcing to Eastern Europe on Productivity and Wages in Austrian Manufacturing", The North American Journal of Economics and Finance, 2001 (12).

Falk, Martin and Yvonne Wolfmayr (2005), "Employment effects of Outsourcing to Low Wage Countries: Empirical Evidence for EU Countries", WIFO Working Paper 262/2005, Vienna.

Falk, Martin and Yvonne Wolfmayr (2006), "Austrian FDI in Central-Eastern Europe and Employment in the Home Market", Paper presented at the ETSG-Conference in Vienna 2006. 
Konings, J. and A. Murphy (2001), "Do Multinational Enterprises Substitute Parent Jobs for Foreign Ones? Evidence from European Firm-Level Panel Data", Centre for Economic Policy Research Discussion Paper No. 2972, London.

Kratena, K. and M. Wüger (2001), "Outsourcing, Wettbewerbsfähigkeit und Beschäftigung", WIFOMonatsberichte, 74(4), Vienna.

Marin, Dalia (2004), "A Nation of Poets and Thinkers - Less So With Eastern Enlargement? Austria and Germany", Centre for Economic Policy Research Discussion Paper No. 4358, London.

Meth-Cohn, Delia (2006), "Vienna and the CENTROPE Region: An International Business Perspective", paper presented at an OeNB Workshop on "New Regional Economics in Central European Economies: The Future of CENTROPE", March 30 and 31, 2006.

OECD (2003), OECD Territorial Reviews: Vienna-Bratislava, Austria/Slovak Republic, OECD, Paris.

OECD (2004), Trends in International Migration, OECD, Paris.

Pfaffermayr, M. (2001), "Employment in domestic plants and foreign affiliates: a note on the elasticity of substitution", Weltwirtschaftliches Archiv, Vol. 137(2), pp. 347-64.

Schneider, Friedrich (2006), "Shadow Economies and Corruption all over the World: What Do We Really Know?", IZA Discussion Paper No. 2315, Institute for the Study of Labor (IZA), Bonn, Germany.

Swiss Institute for Business Cycle Research (KOF, 2007), "KOF Index of Globalization 2007”, Press Release, Swiss Institute for Business Cycle Research, Zurich, Switzerland, January 19, 2007. 


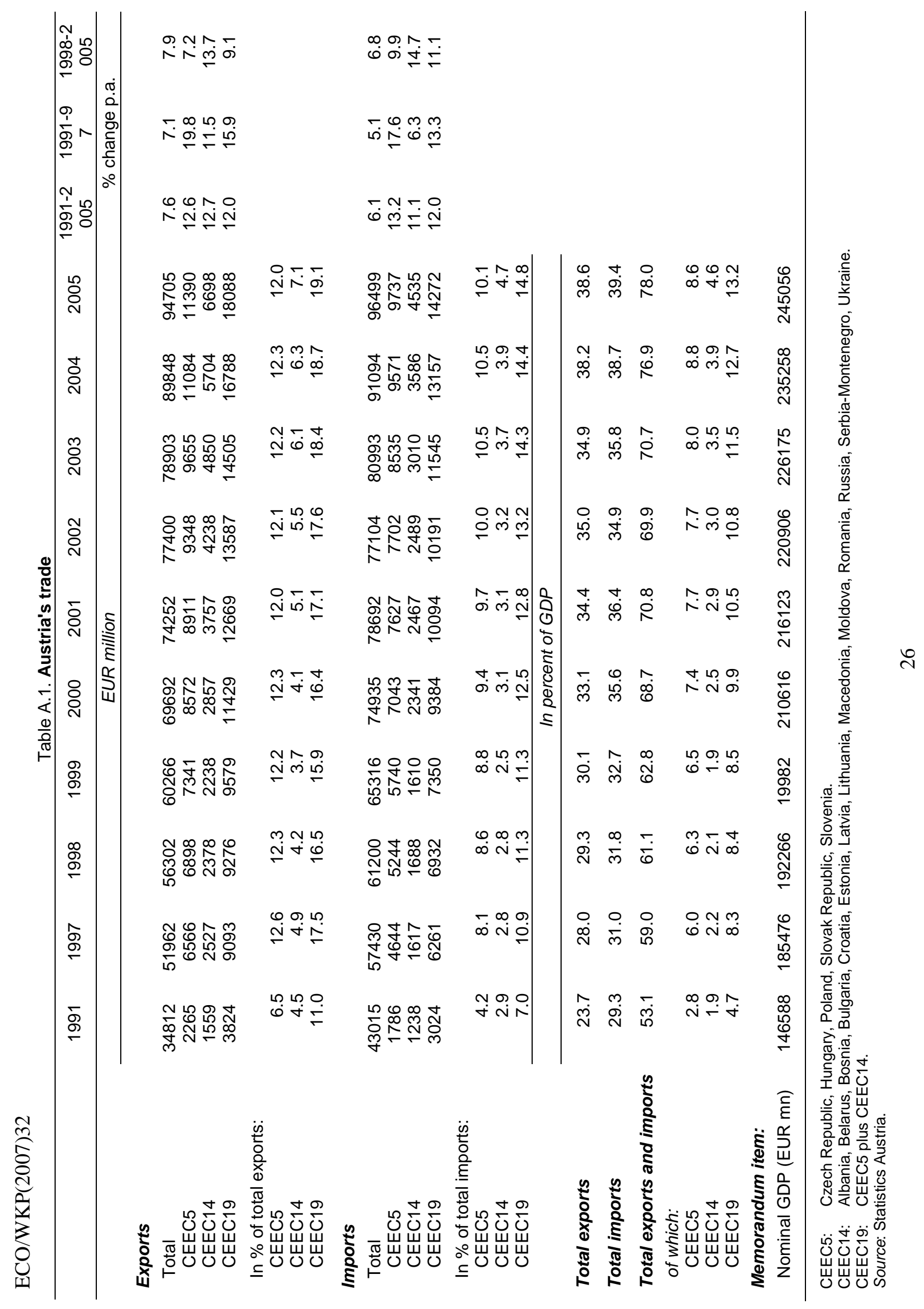




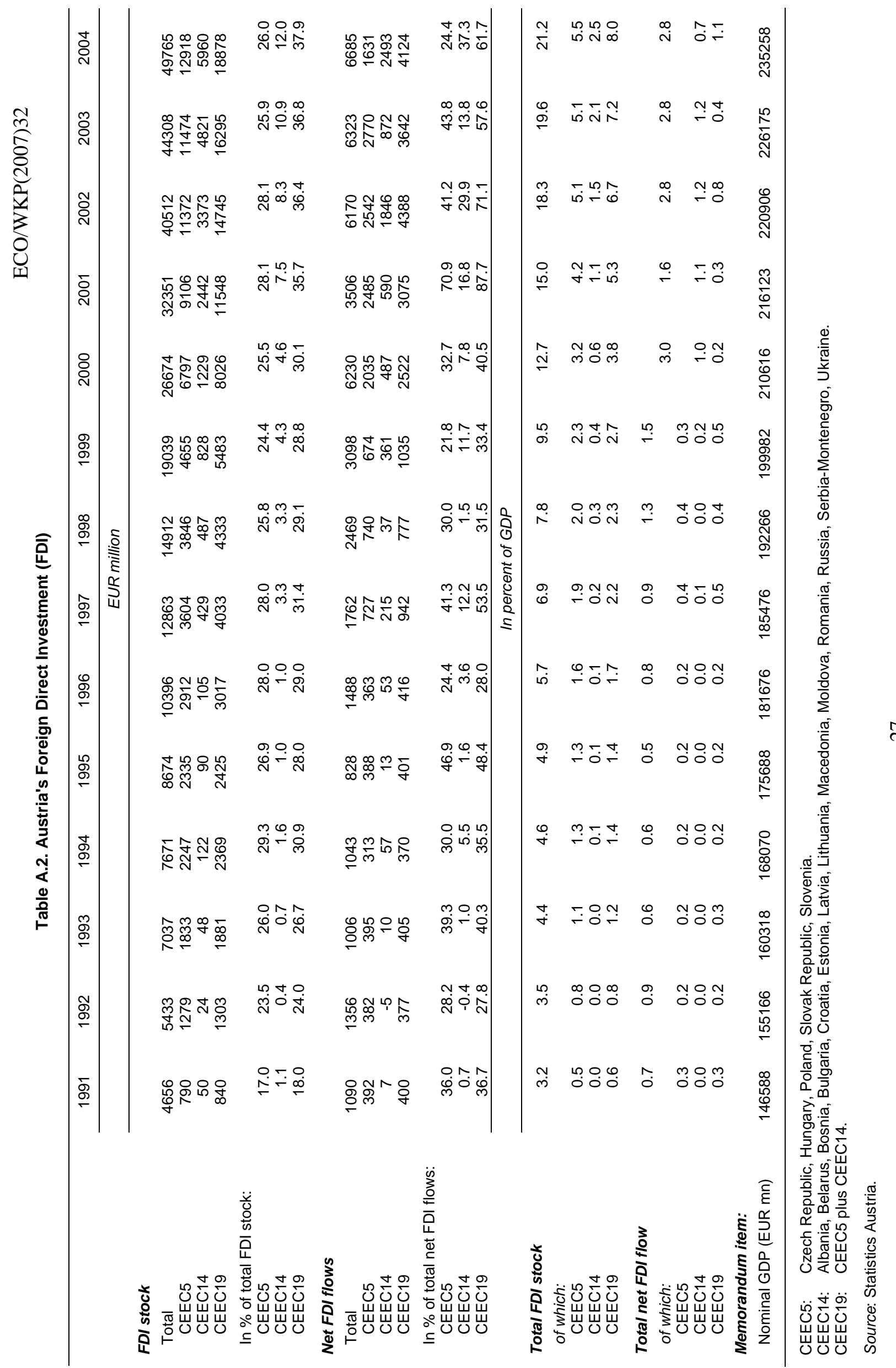


Table A.3. Austria: Structure of Stock of Foreign Direct Investment in Central and Eastern Europe ${ }^{1}$

\begin{tabular}{|c|c|c|c|}
\hline & \multicolumn{3}{|c|}{ Structure in percent } \\
\hline & 1996 & 2004 & Change \\
\hline Mining and quarrying, electricity & 1.3 & 0.8 & -0.5 \\
\hline Food products, agriculture, fishing & 6.5 & 3.0 & -3.4 \\
\hline Textiles, textile products, leather & 0.5 & 0.5 & 0.0 \\
\hline Wood, products of wood and cork & 1.1 & 1.4 & 0.3 \\
\hline Pulp, paper products, printing and publishing & 4.2 & 3.4 & -0.9 \\
\hline Chemical, rubber, plastics, fuel products & 8.1 & 6.6 & -1.5 \\
\hline Other non-metallic mineral products & 8.5 & 3.5 & -5.0 \\
\hline Basic metals, fabricated metal products & 2.8 & 1.2 & -1.6 \\
\hline Machinery and equipment, nes & 1.2 & 0.8 & -0.4 \\
\hline Electrical and optical equipment & 5.7 & 3.5 & -2.2 \\
\hline Transport equipment & 0.6 & 0.6 & 0.0 \\
\hline Manufacturing nes & 0.7 & 0.5 & -0.2 \\
\hline Construction & 5.8 & 2.3 & -3.5 \\
\hline Wholesale and retail trade; repairs & 18.1 & 9.8 & -8.3 \\
\hline Hotels and restaurants & 4.4 & 0.3 & -4.1 \\
\hline Transport, communication & 0.8 & 0.5 & -0.3 \\
\hline Financial intermediation & 20.8 & 46.8 & 26.1 \\
\hline Real estate, business activities & 7.7 & 13.8 & 6.1 \\
\hline Public admin., other services & 1.2 & 0.8 & -0.4 \\
\hline Total & 100.0 & 100.0 & 0.0 \\
\hline of which: Manufacturing & 39.9 & 24.9 & -15.0 \\
\hline
\end{tabular}

1. Czech Republic, Hungary, Poland, Slovak Republic, Slovenia.

Source: Austrian National Bank, OeNB. 


\section{WORKING PAPERS}

The full series of Economics Department Working Papers can be consulted at www.oecd.org/eco/Working_Papers/

572. Austria's deepening economic integration with Central and Eastern Europe (August 2007) Rina Bhattacharya

571. Meeting the challenges of decentralization in France (July 2007) Stéphanie Jamet

Faire face aux défis de la décentralisation en France (juillet 2007) Stéphanie Jamet

570. Enhancing incentives to improve performance in the education system in France (July 2007) Paul O’Brien

Renforcer les incitations à une meilleure performance du système éducatif en France (juillet 2007) Paul O’Brien

569. Combating poverty and social exclusion in France (July 2007) Stéphanie Jamet Lutter contre la pauvreté et l'exclusion social en France (juillet 2007) Stéphanie Jamet

568 The competition law and policy indicator (July 2007) Jens Hoj

567. Structural policies and economic resilience to shocks (July 2007) Romain Duval, Jørgen Elmeskov and Lukas Vogel

566. Family policy in Hungary: how to improve the reconciliation between work and family? (July 2007) Philip Hemmings

565. Encouraging sub-national government efficiency in Hungary (July 2007) Alessandro Goglio

564. Integration of immigrants in OECD countries: do policies matter? (July 2007) Orsetta Causa and Sébastien Jean

563. The unemployment impact of immigration in OECD countries (July 2007) Sébastien Jean and Miguel Jiménez

562. Migration in OECD countries: labour market impact and integration issues (July 2007) Sébastien Jean, Orsetta Causa, Miguel Jiminez and Isabelle Wanner

561. The internationalisation of production, international outsourcing and employment in the OECD (June 2007) Margit Molnar, Nigel Pain and Daria Taglioni

560. Why has Swedish inflation been persistently low? (June 2007) Felix Hüefner

559. The Swedish housing market - better allocation via less regulation (June 2007) Felix Hüefner and Jens Lundsgaard

558 Linkages between performance and institutions in the primary and secondary education sector (June 2007) Douglas Sutherland and Robert Price 


\section{ECO/WKP(2007)32}

557. Toward a more efficient taxation system in New Zealand (June 2007) Annabelle Mourougane

556. Income inequality, poverty and social spending in Japan (June 2007) Randall Jones

555. Improving the efficiency of health care spending: selected evidence on hospital performance (May 2007) Espen Erlandsen

554. Cross-country analysis of efficiency in OECD health care sectors: options for research (May 2007) Unto Häkkinen and Isabelle Joumard

553. What promotes fiscal consolidation: OECD country experience

(May 2007) Stéphanie Guichard, Mike Kennedy, Echkard Wurzel and Christophe André

552. Globalisation and the macroeconomic policy environment

(April 2007) Karine Hervé, Isabell Koske, Nigel Pain, Franck Sédillot

551. Why has core inflation remained so muted in the face of the oil shock?

(April 2007) Paul van den Noord and Christophe André

550. Housing markets and adjustments in monetary union

(April 2007) Peter Hoeller and David Rae

549. Financial markets in Iceland

(March 2007) Peter Tulip

548. The political economy of delaying fiscal consolidation (March 2007) Boris Cournède

547. The impact on growth of higher efficiency of public spending on schools (March 2007) Frédéric Gonand

546. Performance indicators for public spending efficiency in primary and secondary education (February 2007) Douglas Sutherland, Robert Price, Isabelle Joumard and Chantal Nicq

545. Monetary policy and macroeconomic stability in Latin America: the cases of Brazil, Chile, Colombia and Mexico

(February 2007) Luiz de Mello and Diego Moccero

544. The Brazilian "tax war": the case of value-added tax competition among the states (February 2007) Luiz de Mello

543. Public spending efficiency: institutional indicators in primary and secondary education (January 2007) Frédéric Gonand, Isabelle Joumard and Robert Price

542. Enhancing turkey's growth prospects by improving formal sector business conditions (January 2007) Rauf Gönenç, Willi Leibfritz, Gökhan Yilmaz

541. Fiscal relations across levels of government in Australia (January 2007) Vassiliki Koutsogeorgopoulou

540. Russian manufacturing and the threat of 'Dutch Disease': A comparision of competitiveness developments in Russia and Ukrainian industry

(January 2007) Rudiger Ahrend, Donato de Rosa and William Tompson 